\title{
Evidence for an earlier greenhouse cooling effect in the stratosphere before 1980 over the Northern Hemisphere
}

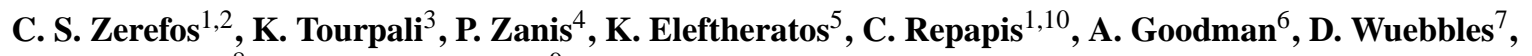 \\ I. S. A. Isaksen ${ }^{8}$, and J. Luterbacher ${ }^{9}$ \\ ${ }^{1}$ Research Centre for Atmospheric Physics and Climatology, Academy of Athens, Athens, Greece \\ ${ }^{2}$ Navarino Environmental Observatory (N.E.O.), Messinia, Greece \\ ${ }^{3}$ Laboratory of Atmospheric Physics, Department of Physics, Aristotle University of Thessaloniki, Thessaloniki, Greece \\ ${ }^{4}$ Department of Meteorology and Climatology, School of Geology, Aristotle University of Thessaloniki, Thessaloniki, Greece \\ ${ }^{5}$ Laboratory of Climatology \& Atmospheric Environment, University of Athens, Athens, Greece \\ ${ }^{6}$ Department of Atmospheric Science, Colorado State University, Fort Collins, CO, USA \\ ${ }^{7}$ Department of Atmospheric Sciences, University of Illinois, Urbana, IL, USA \\ ${ }^{8}$ Department of Geosciences, University of Oslo, Oslo, Norway \\ ${ }^{9}$ Climatology, Climate Dynamics and Climate Change, Department of Geography, Justus-Liebig University of Giessen, \\ Giessen, Germany \\ ${ }^{10}$ Mariolopoulos-Kanaginis Foundation for the Environmental Sciences, Athens, Greece
}

Correspondence to: C. S. Zerefos (zerefos@geol.uoa.gr)

Received: 5 November 2013 - Published in Atmos. Chem. Phys. Discuss.: 14 January 2014

Revised: 23 May 2014 - Accepted: 17 June 2014 - Published: 1 August 2014

Abstract. This study provides a new look at the observed and calculated long-term temperature changes from the lower troposphere to the lower stratosphere since 1958 over the Northern Hemisphere. The data sets include the NCEP/NCAR reanalysis, the Free University of Berlin (FU-Berlin) and the RICH radiosonde data sets as well as historical simulations with the CESM1-WACCM global model participating in CMIP5. The analysis is mainly based on monthly layer mean temperatures derived from geopotential height thicknesses in order to take advantage of the use of the independent FU-Berlin stratospheric data set of geopotential height data since 1957. This approach was followed to extend the records for the investigation of the stratospheric temperature trends to the earliest possible time. After removing the natural variability with an autoregressive multiple regression model our analysis shows that the period 1958-2011 can be divided into two distinct sub-periods of long-term temperature variability and trends: before and after 1980. By calculating trends for the summer time to reduce interannual variability, the two periods are as follows. From 1958 until 1979, a non-significant trend $\left(0.06 \pm 0.06^{\circ} \mathrm{C} \mathrm{decade}^{-1}\right.$ for NCEP $)$ and slightly cooling trends $\left(-0.12 \pm 0.06^{\circ} \mathrm{Cdecade}^{-1}\right.$ for $\mathrm{RICH}$ ) are found in the lower troposphere. The second period from 1980 to the end of the records shows significant warming $\left(0.25 \pm 0.05^{\circ} \mathrm{Cdecade}^{-1}\right.$ for both NCEP and RICH). Above the tropopause a significant cooling trend is clearly seen in the lower stratosphere both in the pre-1980 period $\left(-0.58 \pm 0.17^{\circ} \mathrm{Cdecade}^{-1}\right.$ for NCEP, $-0.30 \pm 0.16^{\circ} \mathrm{Cdecade}^{-1}$ for $\mathrm{RICH}$ and $-0.48 \pm 0.20^{\circ} \mathrm{Cdecade}^{-1}$ for FU-Berlin) and the post-1980 period $\left(-0.79 \pm 0.18^{\circ} \mathrm{Cdecade}^{-1}\right.$ for NCEP, $-0.66 \pm 0.16^{\circ} \mathrm{C} \mathrm{decade}^{-1}$ for RICH and $-0.82 \pm 0.19^{\circ} \mathrm{Cdecade}^{-1}$ for FU-Berlin). The cooling in the lower stratosphere persists throughout the year from the tropics up to $60^{\circ} \mathrm{N}$. At polar latitudes competing dynamical and radiative processes reduce the statistical significance of these trends. Model results are in line with reanalysis and the observations, indicating a persistent cooling $\left(-0.33{ }^{\circ} \mathrm{C}\right.$ decade $\left.^{-1}\right)$ in the lower stratosphere during summer before and after 1980; a feature that is also seen throughout the year. However, the lower stratosphere CESM1-WACCM modelled trends are generally lower than reanalysis and the observations. The contrasting effects of 
ozone depletion at polar latitudes in winter/spring and the anticipated strengthening of the Brewer-Dobson circulation from man-made global warming at polar latitudes are discussed. Our results provide additional evidence for an early greenhouse cooling signal in the lower stratosphere before 1980, which appears well in advance relative to the tropospheric greenhouse warming signal. The suitability of early warning signals in the stratosphere relative to the troposphere is supported by the fact that the stratosphere is less sensitive to changes due to cloudiness, humidity and man-made aerosols. Our analysis also indicates that the relative contribution of the lower stratosphere versus the upper troposphere low-frequency variability is important for understanding the added value of the long-term tropopause variability related to human-induced global warming.

\section{Introduction}

Since the discovery of significant cooling trends in the lower stratosphere in the late 1970s, 1980s and 1990s (Zerefos and Mantis, 1977; Angell and Korshover, 1983; Miller et al., 1992), a number of scientific articles have focused on the statistical space and time continuity of stratospheric temperature observations both from ground and from satellite retrievals. Those publications indicate that the lower stratosphere cooling has continued to the present (Santer et al., 1999, 2013; Randel et al., 2009; WMO, 2011).

Common features in lower-stratospheric temperature change are found in all available radiosonde and satellite data sets $^{1}$. One common finding is that in the global mean, the lower stratosphere has cooled by about $-0.5^{\circ} \mathrm{Cdecade}^{-1}$ since 1980. Randel et al. (2009) reported that lower stratosphere cooling is a robust result over much of the globe for the period 1979-2007, being nearly uniform over all latitudes outside of the polar regions, with some differences among various radiosonde and satellite data sets. Substantially larger cooling trends are observed in the Antarctic lower stratosphere during spring and summer, in association with the development of the Antarctic ozone hole (Randel et al., 2009; Santer et al., 2013). In the tropical lower stratosphere the observations show significant long-term cooling (70-30 hPa) for 1979-2007, while less overall cooling is seen at $100 \mathrm{hPa}$ (Randel et al., 2009). The global-mean lower stratospheric cooling has not occurred linearly, but stems from two downward steps in temperature, both of which are coincident with the cessation of transient warming af-

\footnotetext{
${ }^{1}$ Today, there are six available global lower-stratospheric temperature data sets based on radiosonde data since the late 1950s - RATPAC (Free et al., 2005); HadAT (Thorne et al., 2005); RATPAC-lite (Randel and Wu, 2006); RAOBCORE (Haimberger, 2007); RICH (Haimberger et al., 2008); and IUK (Sherwood et al., 2008) - and three satellite data sets: UAH (Christy et al., 2003); RSS (Mears and Wentz, 2009); and STAR (Zou et al., 2009).
}

ter the volcanic eruptions of El Chichón and Mt Pinatubo (Thompson and Solomon, 2009; Free and Lanzante, 2009). It should be also noted that the global mean lower stratospheric temperatures during the period following 1995 are significantly lower than they were during the decades prior to 1980 , but have not dropped further since 1995 (WMO, 2011). Recently, Thompson et al. (2012) reported that the Stratospheric Sounding Unit (SSU) data reprocessed by NOAA indicate stronger cooling trends in the middle and higher stratosphere than previously estimated, which cannot be captured by the available simulations with coupled chemistry-climate models (CCMs) and coupled atmosphere-ocean global climate models (AOGCMs). This global lower stratosphere cooling since 1980 is also evident in the pre-satellite era with a cooling rate of $\sim 0.35^{\circ} \mathrm{C}$ decade $^{-1}$ since 1958 (WMO, 2011). Randel et al. (2009) questioned the validity of the trends for the period 1958-1978 because of the sparse observational database and the known instrumental uncertainties for this period, together with the large trend uncertainties implied by the spread of results. Furthermore, in other studies it was pointed out that the radiosonde data sets are not fully independent and that there are systematic biases in a number of stations relative to the satellites (Randel and $\mathrm{Wu}$, 2006; Free and Seidel, 2007). These systematic biases are not well understood. Nevertheless, the different statistical approaches applied for homogenization are useful for assessing the overall uncertainty of the long-term stratospheric temperature trend estimates since the late 1950s (WMO, 2011).

The primary radiative forcing mechanisms responsible for global temperature changes in the stratosphere since 1979 have been increases in well-mixed greenhouse gas (GHG) concentrations, increases in stratospheric water vapour, the decrease in stratospheric ozone primarily related to chlorine and bromine from various halocarbons, the effects of aerosols from explosive volcanic eruptions, and the effects of solar activity changes (e.g. Shine et al., 2003; Ramaswamy et al., 2006; WMO, 2007; IPCC, 2007, 2013). The effects of volcanic eruptions, variations in solar radiation, and other sources of natural variability, including the wave-driven quasi-biennial oscillation (QBO) in ozone, can be accounted for through the use of indices in time series trend analyses (Tiao et al., 1990; Staehelin et al., 2001; Reinsel et al., 2005; Fioletov, 2009). However, the attribution of past lower stratosphere temperature trends is complicated by the effects of the increases and levelling off of ozone-depleting substances (ODSs) and the inter-annual to decadal variability of the Brewer-Dobson (BD) circulation.

The expectation of an accelerated and stronger BD circulation in a warmer climate is consistent with results from transport chemistry climate model simulations, wherein the lower stratospheric temperature trends may result from increases in upwelling over the tropical lower stratosphere and strengthening of the BD circulation (Rind et al., 2001; Cordero and Forster, 2006; Butchart et al., 2006, 2010; Austin and Li, 2006; Rosenlof and Reid, 2008; Garcia and Randel, 2008; 
Lamarque and Solomon, 2010). Unfortunately, the detection of trends in the BD circulation in observations is complicated because trends in BD circulation are small from 1980 through 2010 but are expected to become larger in the next few decades (Butchart, 2014). In addition, the BD circulation is not a directly observed physical quantity (WMO, 2011). Yet, observational evidence of an accelerated BD has been shown in a number of studies over both the tropics (e.g. Thompson and Solomon; 2005, Rosenlof and Reid, 2008) and the high latitudes (Johanson and $\mathrm{Fu}, 2007 ; \mathrm{Hu}$ and Fu, 2009; Lin et al., 2009; Fu et al., 2010). Thompson and Solomon (2009) have shown that the contrasting latitudinal structures of recent stratospheric temperature and ozone trends are consistent with the assumption of increases in the stratospheric overturning BD circulation. Also Free (2011) pointed out that trends in the tropical stratosphere show an inverse relationship with those over the Arctic for 1979-2009, which might be related to changes in stratospheric circulation. In contrast, other studies using balloon-borne measurements of stratospheric trace gases over the past 30 years to derive the mean age of air from sulfur hexafluoride $\left(\mathrm{SF}_{6}\right)$ and $\mathrm{CO}_{2}$ mixing ratios, found no indication of an increasing meridional circulation (Engel et al., 2009). Furthermore, Iwasaki et al. (2009) pointed out that the yearly trends in BD strength, diagnosed from all re-analyses products over the common period 1979-2001, are not reliably observed due to large diversity among the reanalyses. According to Randel and Thompson (2011), since there are no direct measurements of upwelling near the tropical tropopause, and there are large uncertainties in indirect measurements or assimilated data products (Iwasaki et al., 2009), temperature and ozone observations at the tropics can provide a sensitive measure of upwelling changes in the real atmosphere. In a recent article, Kawatani and Hamilton (2013) reported that a weakening trend in the lower stratosphere QBO amplitude provides strong support for the existence of a long-term trend of enhanced upwelling near the tropical tropopause.

The tropospheric warming and stratospheric cooling associated also with human forcing factors are expected to influence their interface, i.e. the tropopause region (Santer et al., 2003a, b; Seidel and Randel 2006; Son et al., 2009). Seidel and Randel (2006) examined global tropopause variability on synoptic, monthly, seasonal and longer-term timescales using 1980-2004 radiosonde data and reported upward tropopause height trends at almost all of the (predominantly extratropical) stations analysed, yielding an estimated global trend of $64 \pm 21 \mathrm{~m} \mathrm{decade}^{-1}$. They reported that on the multidecadal scale the change of the tropopause height is more sensitive to stratospheric temperature changes than to changes in the troposphere over both the tropics and the extratropics. Furthermore, Son et al. (2009) analysed a set of long-term integrations with stratosphere-resolving CCMs, and reported that at northern mid-latitudes, long-term tropopause increase is dominated by the upper troposphere warming. Over the tropics and the Southern Hemisphere extratropics, the long- term tropopause trend is almost equally affected by both the trend in the lower stratosphere and the warming in the upper troposphere (Son et al., 2009).

A major open question that still remains to be answered is whether the stratosphere can be considered as a more suitable region than the troposphere to detect anthropogenic climate change signals and what can be learned from the long-term stratospheric temperature trends. Indeed, the signal-to-noise ratio in the stratosphere is, radiatively speaking, more sensitive to anthropogenic GHG forcing and less disturbed by the natural variability of water vapour and clouds when compared to the troposphere. This is because (a) the dependence of the equilibrium temperature of the stratosphere on $\mathrm{CO}_{2}$ is larger than that on tropospheric temperature, (b) the equilibrium temperature of the stratosphere depends less upon tropospheric water vapour variability and (c) the influence of cloudiness upon equilibrium temperature is more pronounced in the troposphere than in the stratosphere where the influence decreases with height (Manabe and Weatherald, 1967). Furthermore, anthropogenic aerosols are mainly spread within the lower troposphere (He et al., 2008), and presumably have little effect on stratospheric temperatures.

Another open question is whether the lower stratosphere has been cooling in the time since a reasonable global network became available, i.e. after the International Geophysical Year (IGY) of 1957-1958. Such a long-lasting cooling from the 1960s until today would need to be explained. To what extent are the cooling trends in the lower stratosphere related to human-induced climate change? Has the cooling been accelerating, for instance at high latitudes in winter/spring due to ozone depletion? Has it been interrupted by major volcanic eruptions and El Niño events (Zerefos et al., 1992) or large climatological anomalies?

This study addresses those questions and presents a new look at observed temperature trends over the Northern Hemisphere from the troposphere up to the lower stratosphere in a search for an early warning signal of global warming, i.e. a cooling in the lower stratosphere relative to the warming in the lower atmosphere.

\section{Data and analysis of the statistical methods}

\subsection{Data}

Tropospheric and stratospheric temperature, pressure and geopotential height data used in this study are based on the following sources: (a) the NCEP/NCAR reanalysis I product (NCEP) data from 1958 to 2011 (Kalnay et al., 1996; Kistler et al., 2001), (b) the Free University of Berlin (FU-Berlin) from 1958 to 2001, (c) the Radiosonde Innovation Composite Homogenization (RICH) data (Haimberger, 2007, 2008) from 1958 to 2006 and (d) historical simulations with the NCAR Community Earth System Model (CESM) coupled to the "high-top" Whole Atmosphere Community Climate 
Model (WACCM) CESM1-WACCM (Marsh et al., 2013) from 1958 to 2005. Our analysis is focused on the Northern Hemisphere, as the data coverage in the pre-satellite era has been denser there than in the Southern Hemisphere.

The FU-Berlin is an independent stratospheric analysis data set which is based on earlier subjective analyses of temperature and geopotential height fields at 50,30 and $10 \mathrm{hPa}$ for the Northern Hemisphere, using the 00:00 UT radiosonde reports from the observational network by a team of experienced meteorologists (http://www.geo.fu-berlin.de/en/ met/ag/strat/produkte/fubdata/index.html). Hydrostatic and geostrophic balances were assumed, and observed winds were used to guide the height and temperature analyses. The imposition of these balance conditions ensures a consistent data set. In addition, temporal continuity is assured by meteorological control. Note that these balance conditions can result in layer temperatures that deviate from the local radiosonde reports, which include mesoscale structures as well as any random or systematic observational errors (Labitzke et al., 2002; Manney et al., 2004). Earlier studies using the FU-Berlin data set suggest that the approximate geostrophic balance of the upper winds ensures that a contour analysis will be more representative than a temperature analysis based on scattered radiosonde locations (Zerefos and Mantis, 1977; Mantis and Zerefos, 1979). The FU-Berlin analyses thus represent the synoptic-scale structure of the lower and middle stratosphere and the layer mean temperature derived from the thickness is well suited for an investigation of large-scale climatic fluctuations of temperature. The analyses are provided as gridded data sets with a horizontal resolution of $10^{\circ} \times 10^{\circ}$ before 1973 , and $5^{\circ} \times 5^{\circ}$ thereafter. FU-Berlin geopotential height data are available from July 1957 until December 2001 at 100, 50, and $30 \mathrm{hPa}$ (Labitzke et al., 2002). Hence, from the FU-Berlin data set we calculated layer mean temperatures for the two lower stratospheric layers, $100-50 \mathrm{hPa}$ and $50-30 \mathrm{hPa}$. It should be noted that the FU-Berlin data set has provided geopotential height data since 1957, but temperature at the same levels since 1964. Hence, aiming in this study at presenting the stratospheric temperature trends from the earliest possible time, we have used the independent FUBerlin stratospheric data set with layer mean temperature derived from geopotential heights thus extending the records into the past. The variability and trends derived using this data set have been compared to stratospheric data from other sources, both observations and reanalysis. The overall comparison is good, with differences in the variability (in the earlier period before 1980) that can be attributed mainly to the close match between the FU-Berlin analysis and the radiosonde observations (e.g. Randel et al., 2009; Labitzke and Kunze, 2005; Manney et al., 2005; Randel et al, 2004; also in Labitzke et al., 2002 and references therein).

According to WMO (2011), large differences and continuity problems are evident in the middle and upper stratosphere within the reanalysis data sets, implying that trend analysis of stratospheric temperatures for the whole time period should be considered with caution (WMO, 2011). Aware of these problems, we opted here not to use the NCEP product of stratospheric temperature derived at specific atmospheric pressure levels, but rather the layer-mean temperature derived from the thickness of stratospheric and tropospheric layers (based on the geopotential height differences between specific atmospheric pressure levels) for comparison purposes with the respective quantities of the FUBerlin data set. Differences of monthly mean geopotential heights were used at standard atmospheric levels to derive the layer thickness and subsequently the layer mean temperature. For the NCEP data set we have used the layers $1000-925 \mathrm{hPa}$ (planetary boundary layer), $925-500 \mathrm{hPa}$ (free troposphere), 500-300 hPa (upper troposphere), $100-50 \mathrm{hPa}$ and $50-30 \mathrm{hPa}$ (lower stratosphere). The layer mean temperatures were then used to calculate the averaged layer mean temperature over the latitude belts: northern polar (90$\left.60^{\circ} \mathrm{N}\right)$, northern mid-latitudes $\left(60-30^{\circ} \mathrm{N}\right)$ and the northern tropics $\left(30-5^{\circ} \mathrm{N}\right)$. Furthermore, we also used in our analysis the tropopause pressure from NCEP to study the interannual correlation of tropopause pressure with tropospheric and stratospheric temperatures.

In our analysis we have used simulations with CESM1WACCM, a state-of-the-art "high top" CCM coupled to the Earth system model CESM that extends from the surface to $5.1 \times 10^{-6} \mathrm{hPa}$ (approximately $140 \mathrm{~km}$ ). It has 66 vertical levels and horizontal resolution of $1.9^{\circ}$ latitude by $2.5^{\circ}$ longitude. The historical simulations with CESM1WACCM were carried out as part of phase 5 of the Coupled Model Intercomparison Project (CMIP5). CESM1-WACCM has active ocean and sea ice components as described by Holland et al. (2012). As shown in Marsh et al. (2013) for CESM1-WACCM, an updated parameterization of nonorographic gravity waves led to an improvement in the frequency of Northern Hemisphere $(\mathrm{NH})$ sudden stratospheric warmings (SSWs). Furthermore, the model also includes a representation of the QBO leading to a significant improvement in the representation of ozone variability in the tropical stratosphere compared to observations. The model's chemistry module is based on version 3 of the Model for OZone And Related chemical Tracers (Kinnison et al., 2007). Volcanic aerosol surface area density in WACCM is prescribed from a monthly zonal mean time series derived from observations including the following major volcanic eruptions in historical simulations: Krakatau (1883), Santa Maria (1902), Agung (1963), El Chichón (1982), and Pinatubo (1991). WACCM explicitly represents the radiative transfer of the greenhouse gases $\mathrm{CO}_{2}, \mathrm{CH}_{4}, \mathrm{~N}_{2} \mathrm{O}, \mathrm{H}_{2} \mathrm{O}$, CFC-12 and CFC-11 (which includes also additional halogen species). WACCM simulation used here was performed with all observed forcing from 1955 to 2005 . The observed forcing included changes in surface concentrations of radiatively active species, daily solar spectral irradiance, volcanic sulfate heating and the QBO. A more detailed description of 
the CESM1-WACCM historical simulations can be found in Marsh et al. (2013).

As each source of analysis/reanalysis data spans a different period, the time series were deseasonalized for the period of 1961-1990, common to all data sets. The same procedure was followed for the tropopause pressure. The RICH data set was used at the standard atmospheric levels. The temperature anomalies from the RICH data set available at standard pressure levels were adjusted accordingly. Finally, it should be noted that the selection of various time periods is related to the different time periods of the data sets used, aiming at a more representative comparison among them.

\subsection{Analysis of methods}

A multiple linear regression time series analysis with an autoregressive statistical model is applied on the deseasonalized time series of zonally averaged layer mean temperature similarly to the statistical approach applied by Reinsel et al. (2005). The regression model is of the form

$M(t)=\alpha_{0}+\alpha_{1} t+\Sigma g_{i} Z_{i}+N(t) ; 0<t \leq T$,

where $M(t)$ is the monthly deseasonalized zonal mean temperature and $t$ is the time in months with $t=0$ corresponding to the initial month and $t=T$ corresponding to the last month.

The term $\alpha_{0}$ is an overall level term while $\alpha_{1}$ accounts for a linear trend. The terms $g_{i} Z_{i}$ in the statistical model reflect the temperature variability related to the natural variability, where $Z_{i}$ represent a number of climatic and dynamical indices and $g_{i}$ are the respective regression coefficients. Specifically, the climatic and dynamical indices used here include the 11-year solar cycle (using the solar F10.7 radio flux as a proxy), plus two orthogonal time series to model QBO, namely the standardized zonal wind at 30 and $50 \mathrm{hPa}$ (e.g. Crooks and Gray, 2005; Austin et al., 2009).

It is well known that significant transient warming events occurred in the stratosphere following the volcanic eruptions of Agung (March 1963), El Chichón (April 1982) and Mount Pinatubo (June 1991), and these can substantially influence temperature trend estimates (especially if the volcanic events occur near either end of the time series in question). The common approach in order to avoid a significant influence on trend results is to omit data for 2 years following each eruption in the regression analysis. In order to investigate the role played by stratospheric aerosols, we include terms to account for the influence of stratospheric aerosol variability, using the Stratospheric Aerosol Optical Depth (Sato et al., 1993) as an index in the regression model.

Finally, $N(t)$ is the unexplained noise term. The statistical model is first-order autoregressive $(\operatorname{AR}(1))$, and the term $N(t)$ satisfies

$N(t)=\varphi N(t-1)+e(t)$ where $e(t)$ is an independent random variable with zero mean, commonly known as the white noise residual. This AR(1) model allows for the noise to be (auto)correlated among successive measurements and is typically positive for data which show smoothly varying changes (naturally occurring) in $N(t)$ over time (Reinsel, 2002).

The temperature trends and the role played by the various climatic and dynamic factors described above are examined in detail. The focus is on the detection of trends before and after the beginning of the satellite era (i.e. 1979), a period that is also the benchmark for ozone depletion.

\section{Results}

\subsection{Summer and year-round trends}

In the summer, the stratosphere is less disturbed because it is characterized by lower vertically propagating wave activity from the troposphere, it has smaller natural variability than winter (Webb, 1966; Berger and Lübken, 2011; Gettelman et al., 2011) and it is also not influenced by chemical ozone depletion due to ODSs at high latitudes. Hence the less "noisy" summer records offer the opportunity to investigate for better estimates of the lower stratospheric temperature trends. Figure 1 presents the time series of the layer mean temperatures in summer (June-July-August) for the Northern Hemisphere at tropical, mid and higher latitudinal zones from the lower troposphere up to the stratosphere, calculated from NCEP reanalysis, FU-Berlin and RICH data sets. The thick black lines represent the linear trends before and after 1980, a year that marks the beginning of the availability of satellite data whose inclusion resulted in increased global coverage. Figure 1 shows a consistent cooling of the lower stratosphere in NCEP, FU-Berlin and RICH data sets that persists in both pre- and post-1980 periods. Specifically, for the period 1958-1979, there is a cooling trend for the whole Northern Hemisphere of $-0.58 \pm 0.17^{\circ} \mathrm{C} \mathrm{decade}^{-1}$ in NCEP, $-0.30 \pm 0.16^{\circ} \mathrm{Cdecade}^{-1}$ in $\mathrm{RICH}$ and $-0.48 \pm 0.20^{\circ} \mathrm{Cdecade}^{-1}$ in FU-Berlin. For the common post-1980 period (1980-2001), the respective trends are $-0.79 \pm 0.18^{\circ} \mathrm{Cdecade}^{-1}$ in NCEP, $\quad-0.66 \pm 0.16^{\circ} \mathrm{Cdecade}^{-1}$ for RICH and $-0.82 \pm 0.19^{\circ} \mathrm{Cdecade}^{-1}$ in FU-Berlin. The CESM1WACCM model results agree with reanalysis and the observations, indicating a persistent cooling of the lower stratosphere during summer for the whole Northern Hemisphere by $-0.33 \pm 0.17^{\circ} \mathrm{C} \mathrm{decade}^{-1}$ for $1958-1979$ and by $-0.35 \pm 0.20^{\circ} \mathrm{C} \mathrm{decade}^{-1}$ for $1980-2001$. However, the modelled trends are generally lower than reanalysis and observations. We should point out that our analysis was also performed for the ERA-40 data set (not shown here) with the trend results for the two periods (1958-1979 and 1980-2001) being similar to NCEP trend results. 


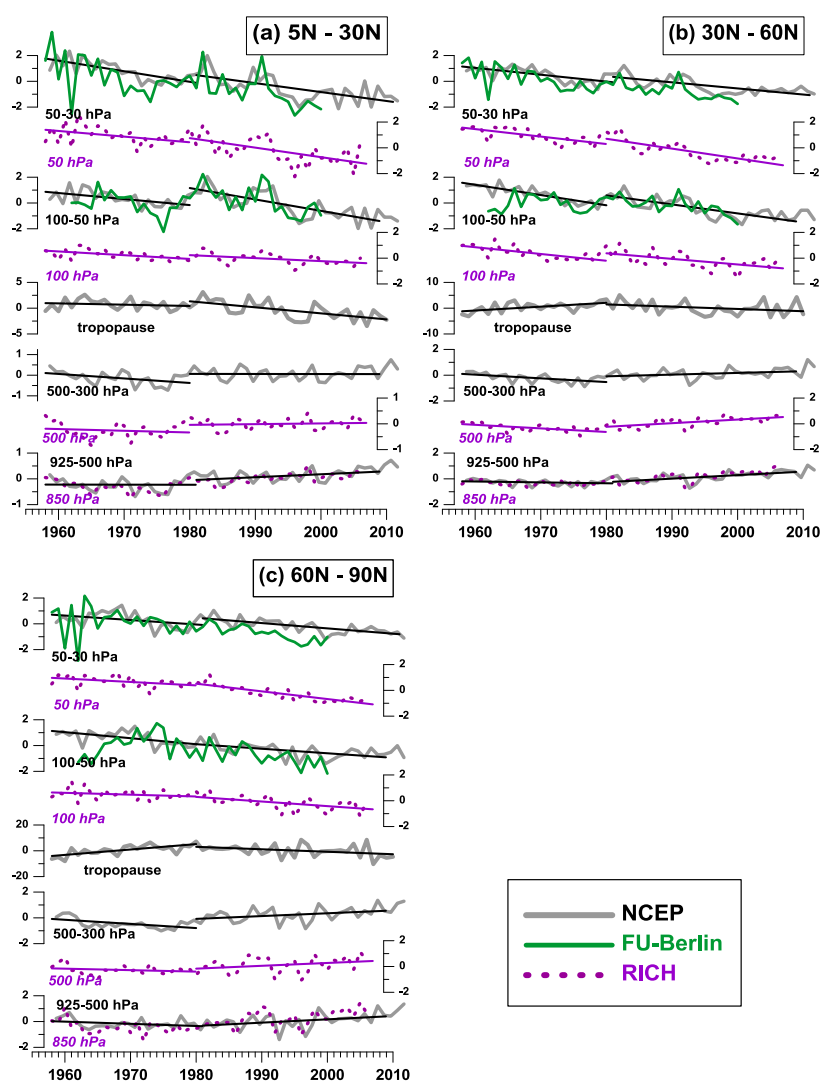

Figure 1. Layer mean temperature variations in Northern Hemisphere summer (JJA) at layers $925-500 \mathrm{hPa}, 500-300 \mathrm{hPa}, 100$ $50 \mathrm{hPa}$ and $50-30 \mathrm{hPa}$ calculated from NCEP reanalysis and FUBerlin data sets and filtered from natural variations for three latitudinal belts: (a) $5-30^{\circ} \mathrm{N}$, (b) $30-60^{\circ} \mathrm{N}$ and (c) $60-90^{\circ} \mathrm{N}$. The respective summer normalized time series of temperature from RICH data set at levels $850,500,50$ and $30 \mathrm{hPa}$ are also illustrated as well as the NCEP tropopause pressure. The trend lines before and after 1979 are superimposed. Grey lines denote NCEP reanalysis variations. Green lines denote variations as depicted in the FU-Berlin analysis, while purple dotted lines denote the RICH data temperature. The units of vertical axes are in ${ }^{\circ} \mathrm{C}$ except for the tropopause which is in $\mathrm{hPa}$.

The summertime lower stratosphere trends at the different latitudinal belts (see Table 1 and Tables S1 and S2 in the Supplement) indicate generally statistically significant (at $95 \%$ ) cooling trends over both pre-1980 and post-1980 periods in the tropics $\left(5-30^{\circ} \mathrm{N}\right)$ and mid-latitudes $\left(30-60^{\circ} \mathrm{N}\right)$ based on NCEP, FU-Berlin and RICH data sets which is also reproduced by CESM1-WACCM (Table 2). However, in polar regions $\left(60-90^{\circ} \mathrm{N}\right)$, the lower stratosphere cooling trends are either non-statistically significant or marginally significant at the $95 \%$ confidence level for NCEP, FU-Berlin and RICH data sets. The same result is also indicated in CESM1WACCM simulation (Table 2).

In the lower Northern Hemispheric troposphere (1000$500 \mathrm{hPa}$ ), non-statistically significant (at 95\%) trends or slight cooling trends prevail in the period 1958$1979\left(0.06 \pm 0.06\right.$ for NCEP and $-0.12 \pm 0.06{ }^{\circ} \mathrm{C}$ decade $^{-1}$ for $\mathrm{RICH}$ ) followed by significant warming trends over the period $1980-2005\left(0.25 \pm 0.05^{\circ} \mathrm{Cdecade}^{-1}\right.$ for both NCEP and RICH). CESM1-WACCM shows a persistent warming of the lower troposphere during summer by $0.21 \pm 0.17^{\circ} \mathrm{Cdecade}^{-1}$ in the pre-1980 period and $0.21 \pm 0.14^{\circ} \mathrm{C} \mathrm{decade}^{-1}$ in the post-1980 period. However, when excluding the polar latitudes, CESM1WACCM shows a non-statistically significant (at 95\%) trend in the period $1958-1979\left(0.04 \pm 0.12^{\circ} \mathrm{C} \mathrm{decade}^{-1}\right)$ followed by a warming trend over the period 1980-2005 $\left(0.22 \pm 0.11^{\circ} \mathrm{Cdecade}^{-1}\right)$ in agreement with NCEP and $\mathrm{RICH}$.

The NCEP tropopause pressure follows closely (but in reverse) the tropospheric temperature long-term change with tropopause pressure increasing in the pre-1980 period (tropopause height decreases) and decreasing in the post1980 period (tropopause height increases) in all three latitude zones. It should be pointed out that the increasing trend of tropopause pressure over the tropics in the pre-1980 period is small and not statistically significant at $95 \%$ level. The summer CESM1-WACCM tropopause pressure trends (Table 2) generally agree within 1-sigma with the respective NCEP trends (Table 1) with the exception of the mid-latitudes of the pre-1980 period where CESM1-WACCM shows a statistical significant decreasing trend (tropopause height increases).

The year-round temperature and tropopause trends (Fig. 2) generally show similar results to those derived for the summer period (see also Supplement Tables S3-S6). In the lower stratosphere, the layer mean temperatures are decreasing continuously from the late 1950s onwards. Specifically, for the period 1958-1979, there is a cooling trend for the whole Northern Hemisphere of $-0.58 \pm 0.08^{\circ} \mathrm{C} \mathrm{decade}^{-1}$ in NCEP, $-0.33 \pm 0.08^{\circ} \mathrm{Cdecade}^{-1}$ in RICH and $-0.44 \pm 0.10^{\circ} \mathrm{Cdecade}^{-1}$ in FU-Berlin. For the common to all data sets period $1980-2001$, the respective trends are $-0.76 \pm 0.09^{\circ} \mathrm{Cdecade}^{-1}$ in NCEP, $\quad-0.64 \pm 0.08^{\circ} \mathrm{C} \mathrm{decade}^{-1}$ for RICH and $-0.71 \pm 0.10^{\circ} \mathrm{Cdecade}^{-1}$ in FU-Berlin. The CESM1WACCM model also shows a persistent cooling of the lower stratosphere by $-0.40 \pm 0.09^{\circ} \mathrm{Cdecade}^{-1}$ for $1958-1979$ and by $-0.24 \pm 0.10^{\circ} \mathrm{Cdecade}^{-1}$ for $1980-2001$. The decreasing trends of lower stratospheric temperatures are statistically significant (at $95 \%$ confidence level) in the tropical belt $\left(5-30^{\circ} \mathrm{N}\right)$ and the mid-latitudes $\left(30-60^{\circ} \mathrm{N}\right)$ for all data sets. For the polar latitudes $\left(60-90^{\circ} \mathrm{N}\right)$, it should be noted that there is a non-statistically significant (95\%) small negative temperature (or even positive) trend during the pre-1980 period at the lower stratosphere in both RICH and FU-Berlin data sets in contrast to NCEP and CESM1-WACCM. For the post- 1980 period in the lower stratosphere over polar latitudes all data sets indicate statistically significant cooling trends but with the tension in CESM1-WACCM simulation for a smaller cooling trend. 
Table 1. Trend calculations in Northern Hemisphere summer (JJA) based on the monthly normalized time series of the layer mean temperature $\left({ }^{\circ} \mathrm{C} \mathrm{decade}^{-1}\right)$ and tropopause pressure (TP; $\left.\mathrm{hPadecade}{ }^{-1}\right)$ calculated from NCEP reanalysis and filtered from natural variations at the latitudinal belts: (a) $5-30^{\circ} \mathrm{N}$, (b) $30-60^{\circ} \mathrm{N}$ and (c) $60-90^{\circ} \mathrm{N}$. The layers are as follows: L1: 1000-925 hPa, L2: 925-500 hPa, L3: 500$300 \mathrm{hPa}, \mathrm{L} 4:$ 100-50 hPa and L5: 50-30 hPa. The trend calculations refer to the periods 1958-1979, 1980-2001, 1980-2005 and 1980-2011.

\begin{tabular}{|c|c|c|c|c|c|c|}
\hline \multirow{2}{*}{ Layer } & \multicolumn{2}{|c|}{$90-60^{\circ} \mathrm{N}$} & \multicolumn{2}{|c|}{$60-30^{\circ} \mathrm{N}$} & \multicolumn{2}{|c|}{$30-05^{\circ} \mathrm{N}$} \\
\hline & Trend & $t$ test & Trend & $t$ test & Trend & $t$ test \\
\hline \multicolumn{7}{|c|}{ Period 1958-1979 } \\
\hline L1 & $0.26 \pm 0.11$ & 2.48 & $-0.01 \pm 0.04$ & -0.25 & $0.11 \pm 0.03$ & 3.91 \\
\hline L2 & $0.10 \pm 0.09$ & 1.12 & $-0.11 \pm 0.04$ & -2.92 & $-0.01 \pm 0.04$ & -0.22 \\
\hline L3 & $-0.42 \pm 0.07$ & -5.69 & $-0.25 \pm 0.04$ & -6.89 & $-0.11 \pm 0.05$ & -2.19 \\
\hline L4 & $-0.57 \pm 0.31$ & -1.83 & $-0.59 \pm 0.06$ & -10.37 & $-0.21 \pm 0.12$ & -1.79 \\
\hline L5 & $-0.77 \pm 0.35$ & -2.19 & $-0.74 \pm 0.09$ & -8.38 & $-0.59 \pm 0.10$ & -5.99 \\
\hline $\mathrm{TP}$ & $1.98 \pm 1.25$ & 1.58 & $2.42 \pm 0.28$ & 8.57 & $0.19 \pm 0.24$ & 0.78 \\
\hline \multicolumn{7}{|c|}{ Period 1980-2001 } \\
\hline L1 & $0.39 \pm 0.11$ & 3.42 & $0.23 \pm 0.04$ & 5.31 & $0.06 \pm 0.03$ & 2.00 \\
\hline L2 & $0.05 \pm 0.09$ & 0.56 & $0.19 \pm 0.04$ & 4.74 & $0.04 \pm 0.04$ & 0.93 \\
\hline L3 & $0.14 \pm 0.08$ & 1.83 & $0.07 \pm 0.04$ & 1.50 & $-0.10 \pm 0.05$ & -2.20 \\
\hline L4 & $-0.70 \pm 0.34$ & -2.04 & $-0.94 \pm 0.07$ & -14.14 & $-0.90 \pm 0.11$ & -8.30 \\
\hline L5 & $-0.66 \pm 0.36$ & -1.84 & $-0.83 \pm 0.08$ & -10.02 & $-0.73 \pm 0.09$ & -8.20 \\
\hline $\mathrm{TP}$ & $-1.87 \pm 1.69$ & -1.10 & $-1.59 \pm 0.35$ & -4.52 & $-0.82 \pm 0.24$ & -3.43 \\
\hline \multicolumn{7}{|c|}{ Period 1980-2005 } \\
\hline L1 & $0.61 \pm 0.09$ & 6.75 & $0.28 \pm 0.03$ & 8.31 & $0.11 \pm 0.02$ & 5.51 \\
\hline L2 & $0.14 \pm 0.07$ & 2.07 & $0.24 \pm 0.03$ & 7.81 & $0.11 \pm 0.03$ & 3.67 \\
\hline L3 & $0.23 \pm 0.06$ & 3.91 & $0.11 \pm 0.03$ & 3.20 & $-0.01 \pm 0.03$ & -0.35 \\
\hline L4 & $-0.43 \pm 0.26$ & -1.61 & $-0.69 \pm 0.06$ & -11.86 & $-0.79 \pm 0.08$ & -9.51 \\
\hline L5 & $-0.46 \pm 0.28$ & -1.66 & $-0.63 \pm 0.07$ & -9.14 & $-0.55 \pm 0.08$ & -6.90 \\
\hline TP & $-1.06 \pm 1.30$ & -0.82 & $-0.72 \pm 0.27$ & -2.68 & $-0.75 \pm 0.18$ & -4.14 \\
\hline \multicolumn{7}{|c|}{ Period 1980-2011 } \\
\hline L1 & $0.65 \pm 0.07$ & 9.18 & $0.29 \pm 0.03$ & 10.83 & $0.13 \pm 0.02$ & 7.85 \\
\hline L2 & $0.25 \pm 0.05$ & 4.68 & $0.27 \pm 0.03$ & 10.50 & $0.16 \pm 0.02$ & 6.40 \\
\hline L3 & $0.28 \pm 0.05$ & 5.99 & $0.16 \pm 0.03$ & 5.91 & $0.07 \pm 0.03$ & 2.22 \\
\hline L4 & $-0.32 \pm 0.22$ & -1.50 & $-0.53 \pm 0.05$ & -10.03 & $-0.67 \pm 0.07$ & -10.21 \\
\hline L5 & $-0.38 \pm 0.22$ & -1.70 & $-0.45 \pm 0.06$ & -7.59 & $-0.41 \pm 0.06$ & -6.51 \\
\hline $\mathrm{TP}$ & $-1.49 \pm 1.07$ & -1.40 & $-1.07 \pm 0.25$ & -4.23 & $-0.91 \pm 0.15$ & -5.92 \\
\hline
\end{tabular}

In the lower troposphere over the Northern Hemisphere, an insignificant change or a small cooling trend from the beginning of our data sets through to the end of the $1970 \mathrm{~s}\left(0.01 \pm 0.03\right.$ for NCEP and $-0.13 \pm 0.03{ }^{\circ} \mathrm{C}$ decade $^{-1}$ for $\mathrm{RICH})$ is followed by a statistically significant warming trend in the post-1980 period $(0.30 \pm 0.02$ for NCEP and $0.27 \pm 0.02^{\circ} \mathrm{C} \mathrm{decade}^{-1}$ for RICH). CESM1-WACCM shows a persistent warming of the lower troposphere during summer by $0.23 \pm 0.09^{\circ} \mathrm{C} \mathrm{decade}^{-1}$ in the pre-1980 period and $0.28 \pm 0.07^{\circ} \mathrm{C} \mathrm{decade}^{-1}$ in the post-1980 period. Tropospheric temperature trends in CESM1-WACCM simulations (see Supplement Table S6) generally agree within 1-sigma with NCEP temperature trends before and after 1980 with the exception of the pre-1980 trend in polar latitudes showing a statistical significant warming in contrast to NCEP and RICH data sets. When excluding the polar lat- itudes, CESM1-WACCM shows a non-statistically significant (at 95\%) trend in the period 1958-1979 (0.05 \pm 0.06$)$ followed by a warming trend over the period 1980-2005 $\left(0.24 \pm 0.06^{\circ} \mathrm{Cdecade}^{-1}\right)$ in agreement with NCEP and $\mathrm{RICH}$. It should be noted that the year-round tropospheric temperature trends in the post-1980 period calculated in NCEP (see Supplement Table S3), RICH (see Supplement Table S4) and WACCM model (see Supplement Table S6) for the three latitudinal belts are within the range of respective calculations in previously published work based on different radiosonde data sets (Randel et al., 2009).

The effects of natural forcings derived from our multilinear regression analysis are in generally good agreement with previous studies (e.g. Randel et al., 2009), given that we use layer mean temperatures and different latitude band averages. The effects of solar and volcanic forcing are found 
Table 2. Trend calculations in Northern Hemisphere summer (JJA) based on the monthly normalized time series of the layer mean temperature $\left({ }^{\circ} \mathrm{C} \mathrm{decade}^{-1}\right)$ and tropopause pressure (TP; hPa decade ${ }^{-1}$ ) calculated from the WACCM model and filtered from natural variations at the latitudinal belts: (a) $5-30^{\circ} \mathrm{N}$, (b) $30-60^{\circ} \mathrm{N}$ and (c) $60-90^{\circ} \mathrm{N}$. The layers are as follows: L1: $1000-925 \mathrm{hPa}, \mathrm{L} 2: 925-500 \mathrm{hPa}, \mathrm{L} 3$ : 500-300 hPa, L4: 100-50 hPa and L5: 50-30 hPa. The trends calculations refer to the periods 1958-1979, 1980-2001 and 1980-2005.

\begin{tabular}{|c|c|c|c|c|c|c|}
\hline \multicolumn{3}{|c|}{$90-60^{\circ} \mathrm{N}$} & \multicolumn{2}{|c|}{$60-30^{\circ} \mathrm{N}$} & \multicolumn{2}{|c|}{$30-05^{\circ} \mathrm{N}$} \\
\hline Layer & Trend & $t$ test & Trend & $t$ test & Trend & $t$ test \\
\hline \multicolumn{7}{|c|}{ Period 1958-1979 } \\
\hline $\mathrm{L} 1$ & $0.70 \pm 0.45$ & 1.55 & $0.01 \pm 0.32$ & 0.02 & $-0.02 \pm 0.10$ & -0.16 \\
\hline L2 & $0.37 \pm 0.09$ & 4.23 & $-0.01 \pm 0.04$ & -0.20 & $0.19 \pm 0.02$ & 8.66 \\
\hline L3 & $0.13 \pm 0.06$ & 2.14 & $0.02 \pm 0.04$ & 0.43 & $0.24 \pm 0.03$ & 7.83 \\
\hline L4 & $-0.26 \pm 0.32$ & -0.81 & $-0.22 \pm 0.10$ & -2.25 & $-0.30 \pm 0.09$ & -3.22 \\
\hline L5 & $-0.28 \pm 0.35$ & -0.80 & $-0.32 \pm 0.13$ & -2.41 & $-0.57 \pm 0.10$ & -5.80 \\
\hline $\mathrm{TP}$ & $0.33 \pm 1.13$ & 0.29 & $-1.42 \pm 0.45$ & -3.14 & $-0.57 \pm 0.53$ & -1.07 \\
\hline \multicolumn{7}{|c|}{ Period 1980-2001 } \\
\hline $\mathrm{L} 1$ & $0.14 \pm 0.42$ & 0.33 & $0.12 \pm 0.36$ & 0.34 & $0.40 \pm 0.10$ & 3.97 \\
\hline L2 & $0.40 \pm 0.10$ & 3.90 & $0.29 \pm 0.04$ & 6.67 & $0.22 \pm 0.04$ & 5.14 \\
\hline L3 & $0.33 \pm 0.07$ & 4.64 & $0.26 \pm 0.05$ & 5.25 & $0.29 \pm 0.07$ & 4.31 \\
\hline $\mathrm{L} 4$ & $-0.43 \pm 0.28$ & -1.50 & $-0.16 \pm 0.14$ & -1.19 & $-0.31 \pm 0.15$ & -2.08 \\
\hline L5 & $-0.35 \pm 0.31$ & -1.13 & $-0.40 \pm 0.17$ & -2.40 & $-0.44 \pm 0.16$ & -2.73 \\
\hline $\mathrm{TP}$ & $-2.20 \pm 1.02$ & -2.16 & $-0.75 \pm 0.43$ & -1.74 & $-0.10 \pm 0.53$ & -0.19 \\
\hline \multicolumn{7}{|c|}{ Period 1980-2005 } \\
\hline $\mathrm{L} 1$ & $0.04 \pm 0.32$ & 0.12 & $-0.03 \pm 0.29$ & -0.11 & $0.35 \pm 0.08$ & 4.43 \\
\hline L2 & $0.34 \pm 0.08$ & 4.40 & $0.31 \pm 0.04$ & 8.39 & $0.23 \pm 0.03$ & 7.49 \\
\hline L3 & $0.30 \pm 0.06$ & 5.39 & $0.32 \pm 0.04$ & 7.83 & $0.32 \pm 0.05$ & 6.46 \\
\hline L4 & $-0.52 \pm 0.23$ & -2.30 & $-0.13 \pm 0.10$ & -1.28 & $-0.23 \pm 0.11$ & -2.14 \\
\hline L5 & $-0.46 \pm 0.25$ & -1.85 & $-0.34 \pm 0.13$ & -2.72 & $-0.30 \pm 0.11$ & -2.62 \\
\hline $\mathrm{TP}$ & $-2.87 \pm 0.86$ & -3.35 & $-0.69 \pm 0.34$ & -2.01 & $-0.55 \pm 0.40$ & -1.38 \\
\hline
\end{tabular}

to be more pronounced after 1980. Although the QBO signal is very small and insignificant in the troposphere, we have used the same regression model throughout the atmosphere for uniformity and consistency.

\subsection{Monthly trends}

The temperature trends were also calculated on a monthly basis. The layer mean temperature trends based on NCEP reanalysis (Fig. 3) are persistently negative at the lower stratosphere for all months, for the periods both before and after 1979 at the tropical and mid-latitude latitudinal belts. The monthly temperature trends based on the RICH data set (Fig. 4) and the FU-Berlin data set (Fig. 5) also show persistent negative temperature trends in the lower stratosphere for all months for the periods both before and after 1979 at the tropical and mid-latitude latitudinal belts, in agreement with NCEP. The CESM1-WACCM simulation reproduces the cooling trends in the lower stratosphere for both pre-1980s and post-1980s at the tropical and mid-latitude latitudinal belts (Fig. 6).

At polar latitudes, we find non-statistically significant (at $90 \%$ confidence level) cooling trends for all months in NCEP, except in February-March with a characteris- tic abrupt enhancement of the cooling trend for pre- 1980 (Fig. 3e). In the post-1980 period the cooling trends are nonstatistically significant for all months except for March-April with the strongest cooling signal which might be associated with the Arctic ozone depletion by ODSs (Fig. 3f). In the lower stratosphere over polar latitudes for the pre-1980 period, neither RICH (Fig. 4e) nor FU-Berlin (Fig. 5a and c) data sets show statistically significant (at $90 \%$ confidence level) negative trends. However, it should be noted that the abrupt shift in trend from winter to early spring is a common feature in all three data sets which could be related to dynamical processes and the related variability of the polar vortex. In the post-1980 period both RICH and FU-Berlin data sets indicate cooling trends maximizing in early spring in agreement with the NCEP results presumably due to the ozone depletion issue within the Arctic polar vortex. The CESM1WACCM simulation captures at polar latitudes (Fig. 6e) the abrupt decrease (or elimination) of the cooling trend from winter to early spring for the pre- 1980 period but the winter cooling trends are much stronger than in NCEP, RICH and FU-Berlin data sets. In the post-1980 period the cooling trends are non-statistically significant (at $90 \%$ confidence level) for all months and the early spring cooling trend seen 

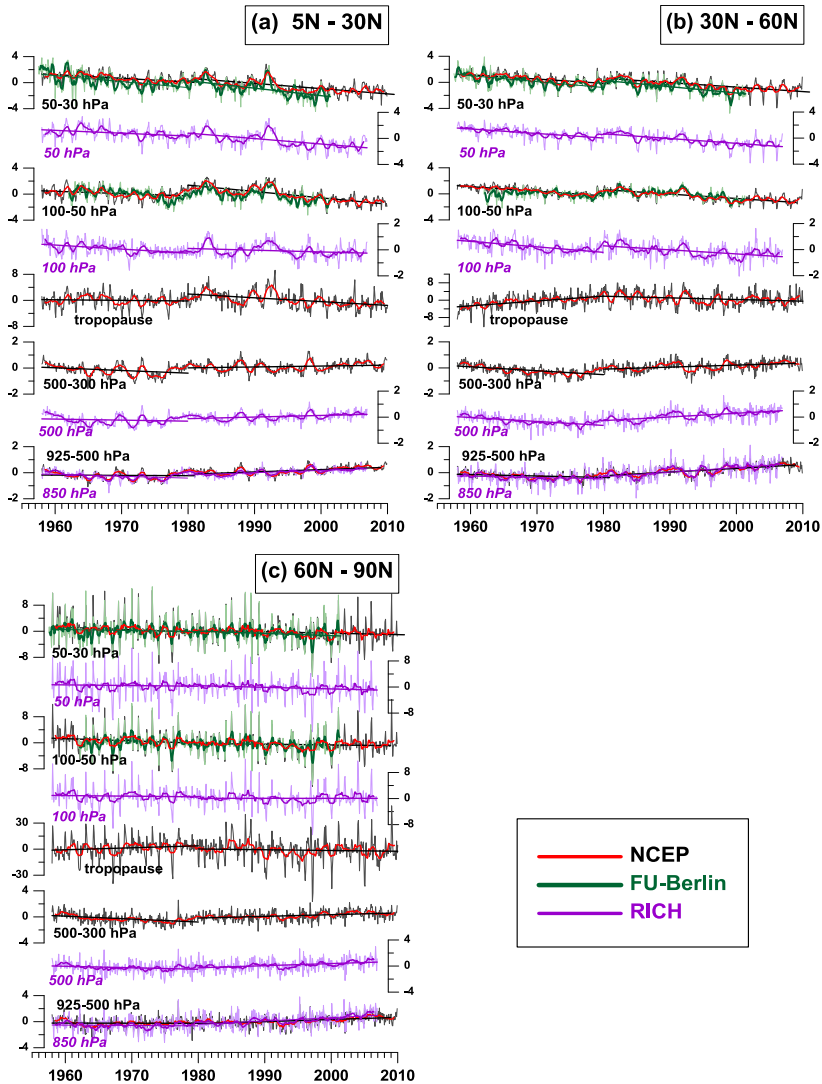

Figure 2. Monthly normalized time series of the layer mean temperature at layers $925-500 \mathrm{hPa}, 500-300 \mathrm{hPa}, 100-50 \mathrm{hPa}$ and 50 $30 \mathrm{hPa}$ calculated from NCEP reanalysis and FU-Berlin data sets for the Northern Hemisphere and filtered from natural variations at the latitudinal belts: (a) $5-30^{\circ} \mathrm{N}$, (b) $30-60^{\circ} \mathrm{N}$ and (c) $60-90^{\circ} \mathrm{N}$. The respective monthly normalized time series of temperature from RICH data set at levels $850,500,50$ and $30 \mathrm{hPa}$ are illustrated with purple lines as well as the NCEP tropopause pressure normalized monthly means. The trend lines before and after 1979 are superimposed. The units of vertical axes are in ${ }^{\circ} \mathrm{C}$ except for the tropopause which is in $\mathrm{hPa}$.

in NCEP, RICH and FU-Berlin data sets (due to ODSs) is not captured or is smaller (Fig. 6f). Overall, all data sets indicate that persistent cooling trends in the lower stratosphere exist in all months and for both periods before and after 1979 which is a robust feature over the tropical belt and the middle latitudes.

\subsection{Tropopause-temperature correlation}

As seen in Figs. 1 and 2, the tropopause pressure follows closely (but reversed) the tropospheric temperature long-term course with a cooling trend or absence of a trend until about the end of the 1970s and a warming trend from about the mid-1980s until the present. Moving up in the lower stratosphere, we have seen that all data sets show persistent cooling temperature trends for both the pre-1980 and post-1980 peri-
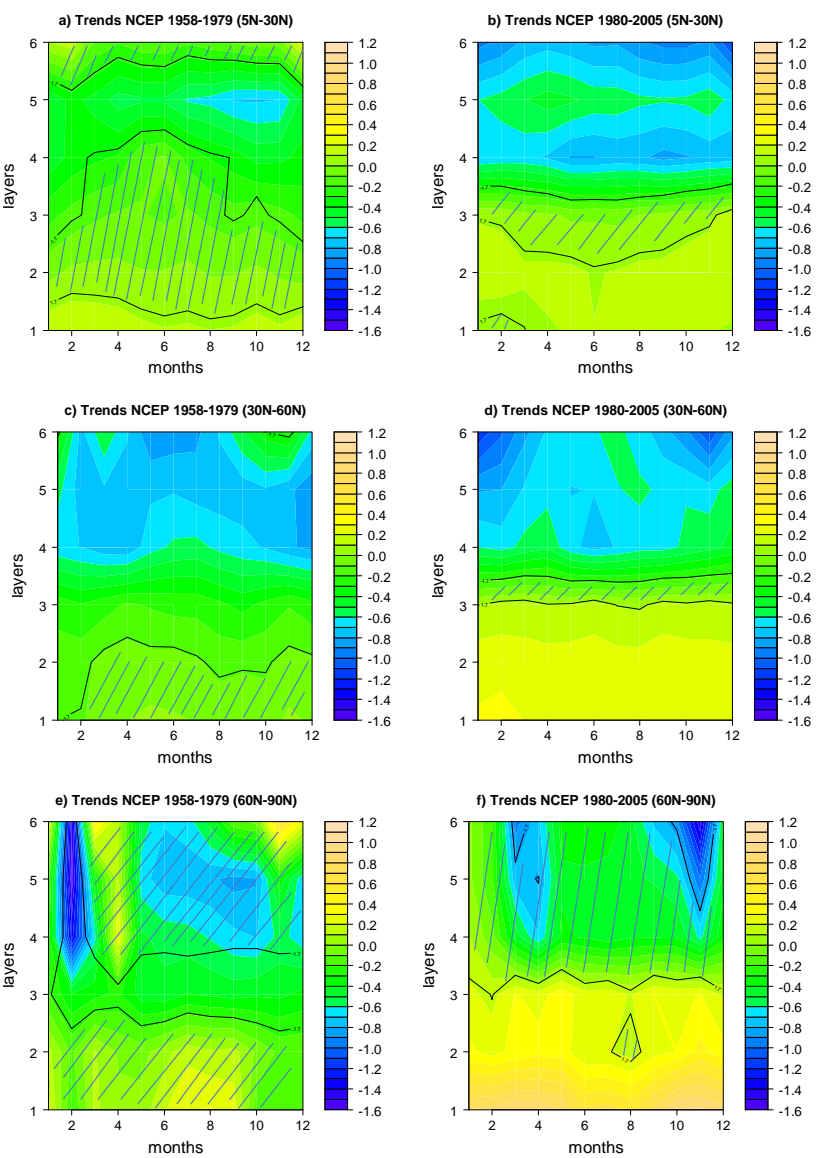

Figure 3. Layer mean temperature trends $\left({ }^{\circ} \mathrm{C}\right.$ decade $\left.{ }^{-1}\right)$ for each month ( $x$ axis) and layer ( $y$ axis) based on NCEP reanalysis over the periods 1958-1979 and 1980-2005, respectively, for three latitudinal belts: (a) and (b) for $5-30^{\circ} \mathrm{N}$, (c) and (d) for $30-60^{\circ} \mathrm{N}$ and (e) and (f) for $60-90^{\circ} \mathrm{N}$. Layer 1: $1000-925 \mathrm{hPa}$, Layer 2: 925-500 hPa, Layer 3: 500-300 hPa, Layer 4: 100-50 hPa, Layer 5: $50-30 \mathrm{hPa}$, and Layer 6: $30-10 \mathrm{hPa}$. The shaded areas are nonstatistically significant at the $90 \%$ confidence level.

ods (Figs. 1 and 2). In this section we investigate the interannual correlation of temperature with tropopause pressure on a monthly basis with the aim of unravelling the relative contribution of tropospheric and stratospheric temperatures on the interannual and long-term variability of tropopause pressure. As has been pointed out in previous studies, the interannual variability and the trends in tropopause height are mainly determined by the interannual variability and the trends of temperature in the lower stratosphere and upper troposphere (Seidel et al., 2006; Son et al., 2009).

At the tropical latitudinal belt $\left(5-30^{\circ} \mathrm{N}\right)$ the Pearson correlation between tropopause pressure and layer mean temperature (based on NCEP reanalysis) is negative in the troposphere ranging from -0.3 to -0.7 becoming positive and stronger in the lower stratosphere ranging from 0.6 to 0.9 (Fig. 7a). The negative correlations in the troposphere have a seasonal signal with the tendency to get stronger during 

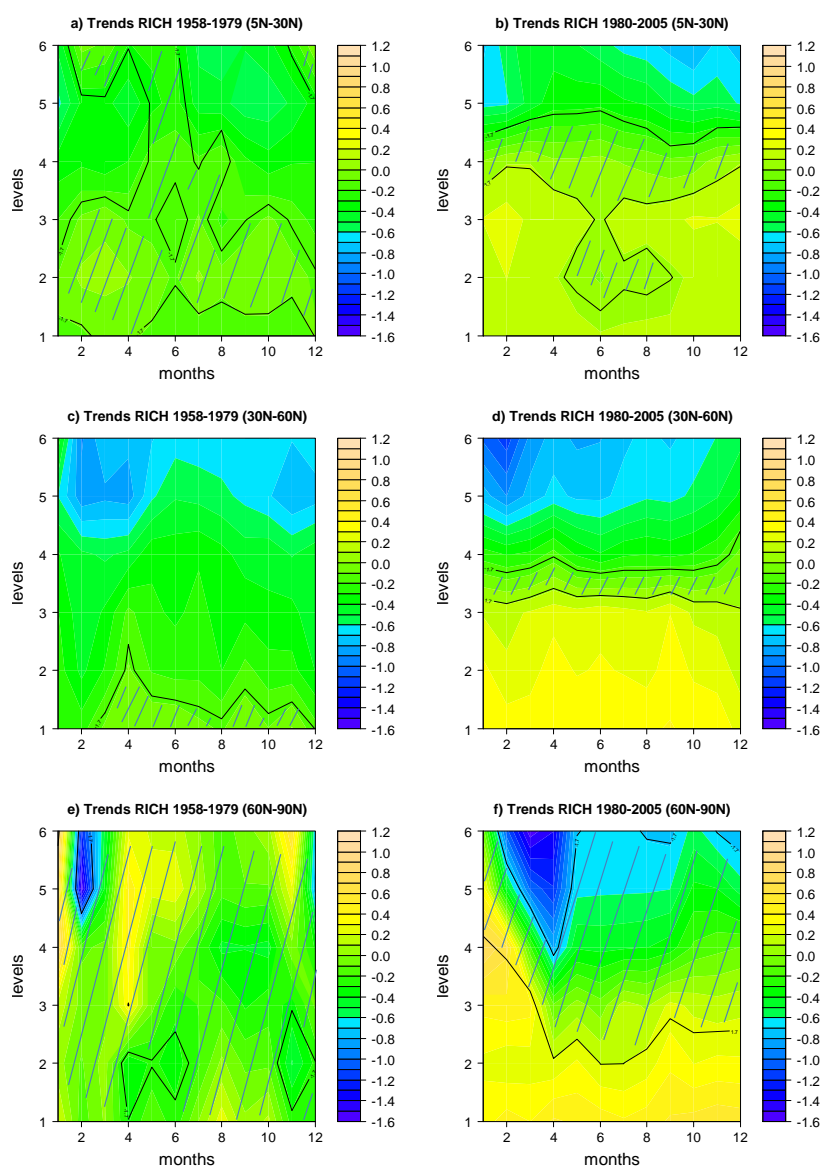

Figure 4. Temperature trends $\left({ }^{\circ} \mathrm{C}\right.$ decade $\left.{ }^{-1}\right)$ for each month $(x$ axis) and level ( $y$ axis) based on RICH data set over the periods 1958-1979 and 1980-2005, respectively, for three latitudinal belts: (a) and (b) for $5-30^{\circ} \mathrm{N}$, (c) and (d) for $30-60^{\circ} \mathrm{N}$ and (e) and (f) for $60-90^{\circ} \mathrm{N}$. Level 1: $850 \mathrm{hPa}$, Level 2: $500 \mathrm{hPa}$, Level 3: $300 \mathrm{hPa}$, Level 4: $100 \mathrm{hPa}$, Level 5: $50 \mathrm{hPa}$, and Level 6: $30 \mathrm{hPa}$. The shaded areas are non-statistically significant at the $90 \%$ confidence level.

the summer period while in the lower stratosphere the strong positive correlation persists throughout the course of the year. Hence it is inferred from Fig. 7a that throughout the year the interannual variance of the lower stratospheric temperatures contributes to the interannual variability at the tropopause region, a higher percentage than that contributed from the variance of tropospheric temperatures. The relative contribution of tropospheric temperatures in the interannual variance at tropopause maximizes during the warm period of the year. CESM1-WACCM (Fig. 7d) reproduces fairly well the correlation pattern of NCEP at the tropical band, thus indicating good skill of the model to simulate the relation in the interannual variability between tropopause height and temperature in the lower stratosphere/upper troposphere region.

At mid-latitudes, the tropopause-temperature correlations in the NCEP data set become weaker, reaching 0.4 in the lower stratosphere and -0.5 in the troposphere mainly from
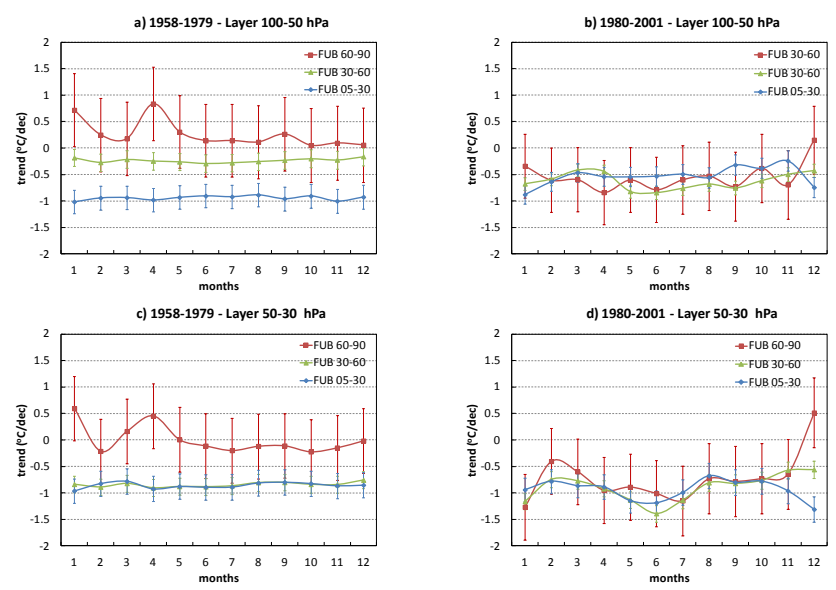

Figure 5. Mean temperature trends $\left({ }^{\circ} \mathrm{C}\right.$ decade $\left.^{-1}\right)$ for each month ( $x$ axis) based on FU-Berlin data set over the periods 1958-1979 and 1980-2001 for the layers $100-50 \mathrm{hPa}(\mathbf{a}$ and b) and $50-30 \mathrm{hPa}$ (c and d) for the three latitudinal belts: $5-30^{\circ} \mathrm{N}$ (blue), $30-60^{\circ} \mathrm{N}$ (green) and 60-90 $\mathrm{N}$ (red).

June to September (Fig. 7b) indicating a higher sensitivity of tropopause interannual changes to tropospheric temperature changes during the warm season. CESM1-WACCM (Fig. 7e) captures the basic pattern of the tropopause-temperature correlations seen in NCEP for mid-latitudes.

At polar latitudes $\left(60-90^{\circ} \mathrm{N}\right)$, the negative correlations (in NCEP) in the troposphere have a seasonal signal with the tendency to get stronger during the warm period of the year reaching a value of -0.7 while in the lower stratosphere the positive correlations become stronger during the cold part of the year reaching a value of 0.8 (Fig. 7c). Thus the interannual variability of lower stratospheric temperature dominates over tropospheric temperature for controlling the interannual variability of the tropopause during the cold part of the year linked with the development of the polar vortex. In contrast, during the warm period of the year, the interannual variability of tropospheric temperature takes over stratospheric temperature, linked to the higher heating rates of the polar troposphere.

The tropopause-temperature correlation pattern in CESM1-WACCM over the polar latitudes (Fig. 7f) is similar to the pattern of mid-latitudes and does not capture the NCEP correlation pattern of polar latitudes. A common feature for the three latitudinal belts and for both NCEP and WACCM is that the negative correlations in the troposphere have a seasonal signal with the tendency to get stronger during the warm part of the year, linked to the more efficient mechanism of tropospheric heating to affect the interannual variability of climate variables at the tropopause region. 

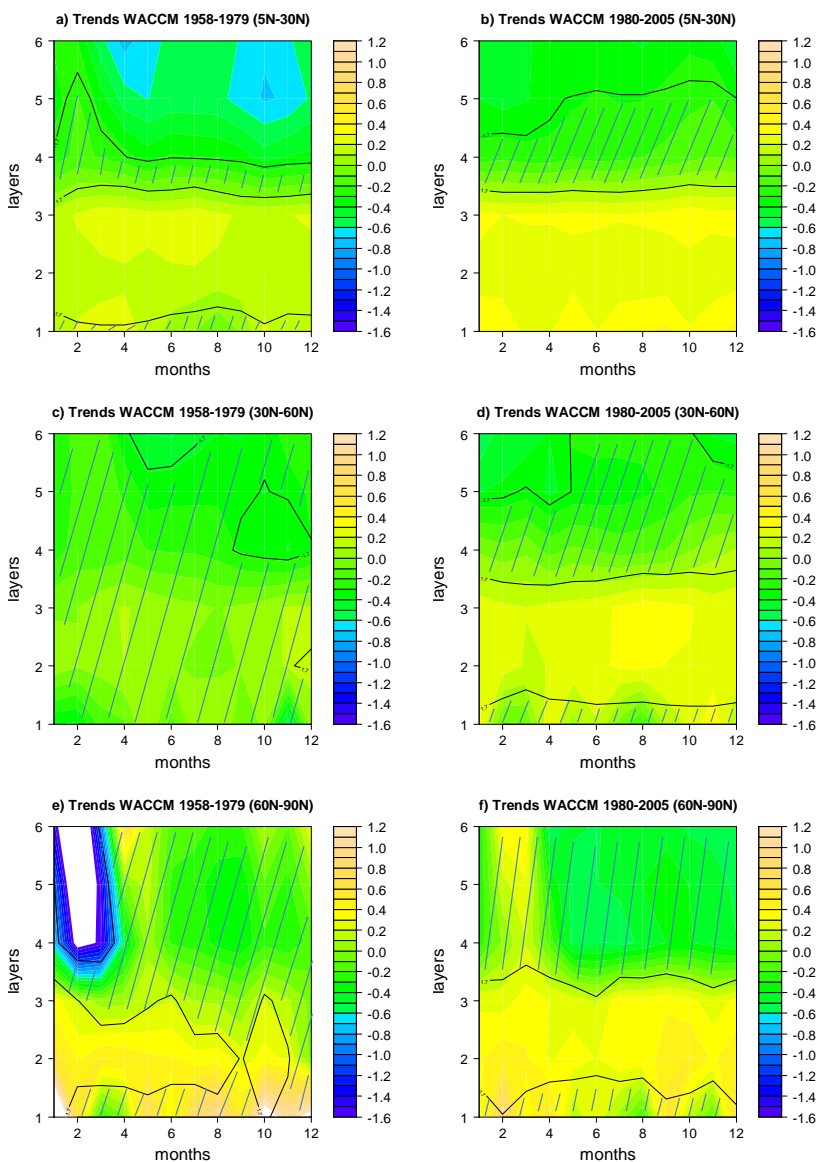

Figure 6. Layer mean temperature trends $\left({ }^{\circ} \mathrm{C}\right.$ decade $\left.{ }^{-1}\right)$ for each month ( $x$ axis) and layer ( $y$ axis) based on WACCM model over the periods 1958-1979 and 1980-2005, respectively, for three latitudinal belts: (a) and (b) for $5-30^{\circ} \mathrm{N}$, (c) and (d) for $30-60^{\circ} \mathrm{N}$ and (e) and (f) for $60-90^{\circ} \mathrm{N}$. Layer 1: 1000-925 hPa, Layer 2: 925-500 hPa, Layer 3: 500-300 hPa, Layer 4: 100-50 hPa, Layer 5: $50-30 \mathrm{hPa}$, and Layer 6: $30-10 \mathrm{hPa}$. The shaded areas are nonstatistically significant at the $90 \%$ confidence level.

\section{Discussion and concluding remarks}

We presented the stratospheric temperature trends from the late 1950s using the independently produced FU-Berlin stratospheric data set comprising monthly layer mean temperatures derived from geopotential heights together with other analysis using reanalysis and radiosonde data over the Northern Hemisphere. After removing the natural variability with the use of climatic and dynamical indices in a statistical autoregressive multiple regression model, the calculated year-round trends showed a persistent decrease in temperatures in the lower stratosphere since the late 1950s. This is also confirmed by applying the interannual trend analyses separately for the summer when the stratosphere is less disturbed, the BD circulation is weaker and it is also not influenced at high latitudes by the chemical ozone depletion due to ODSs found in the winter-early spring period
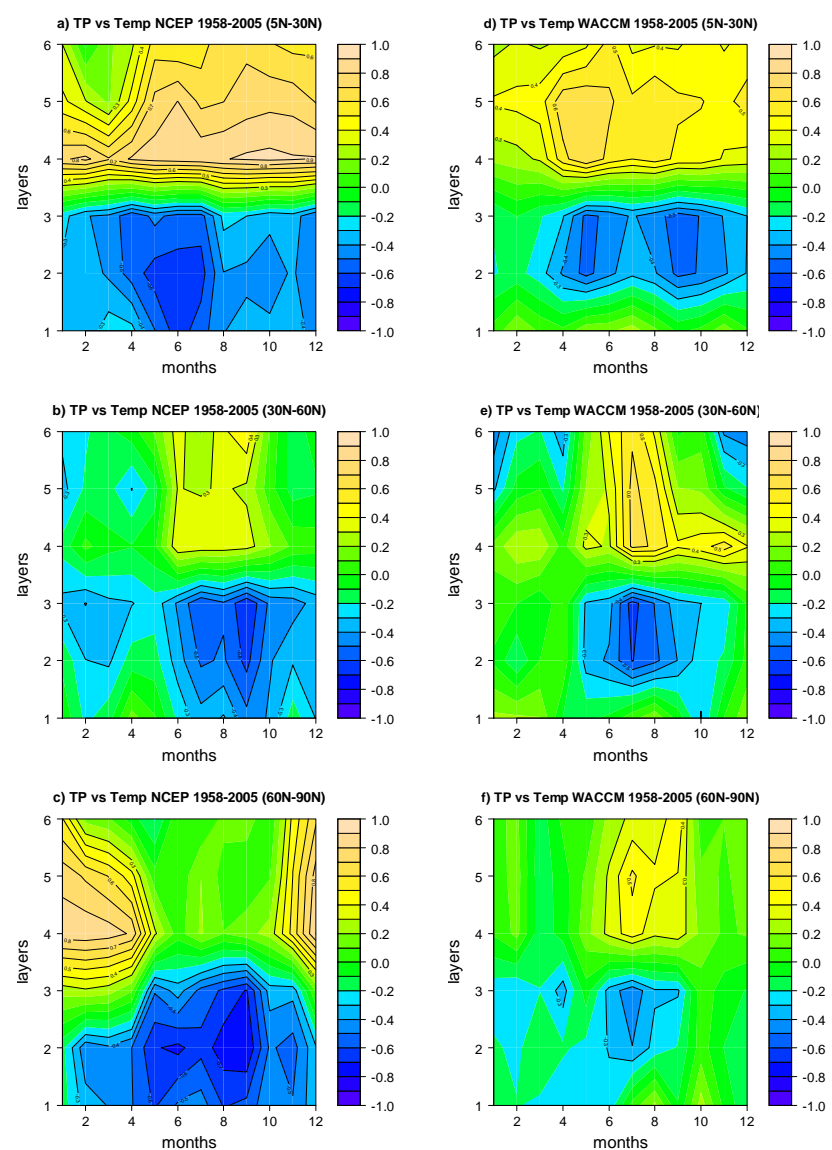

Figure 7. Correlation plots between tropopause pressure and layer mean temperature for each month ( $x$ axis) and layer ( $y$ axis) based on NCEP reanalysis (left panel) and WACCM model (right panel) over the common period 1958-2005 for the three latitudinal belts: $5-30^{\circ} \mathrm{N}$ (a and d), $30-60^{\circ} \mathrm{N}$ (b and e) and $60-90^{\circ} \mathrm{N}$ (c and f). Layer 1: $1000-925 \mathrm{hPa}$, Layer 2: $925-500 \mathrm{hPa}$, Layer 3: 500 $300 \mathrm{hPa}$, Layer 4: $100-50 \mathrm{hPa}$, Layer 5: $50-30 \mathrm{hPa}$, and Layer 6: $30-10 \mathrm{hPa}$. The contours indicate the statistically significant correlations at the $95 \%$ significance level with $\rho>0.3$ or $\rho<-0.3$.

(e.g. Harris et al., 2008). These decreasing lower stratosphere trends are robust features for NCEP, FU-Berlin and RICH data sets in the tropics and the middle latitudes. The CESM1WACCM simulation reproduces the lower stratosphere cooling trends before and after the 1980s in the tropics and over mid-latitudes, consistent with an increased infrared emission by $\mathrm{CO}_{2}$ (Marsh et al., 2013). It should be noted that modelled trends in the lower stratosphere were found to be generally lower than those found in the reanalysis and the observations. This result is in agreement with the study by Santer et al. (2013) who showed that on average the CMIP5 models analysed underestimate the observed cooling of the lower stratosphere which may be due to the need for a more realistic treatment of stratospheric ozone depletion and volcanic aerosol forcing. 
It should be pointed out that the temperature long-term trends based on RICH are within 1-sigma of the thickness calculated layer temperature trends from FU-Berlin and NCEP data sets, indicating a consistent picture for the cooling trend of the lower stratosphere before and after 1980. The consistency of RICH temperature trends with the thickness calculated layer mean temperature trends from FU-Berlin and NCEP enhances our confidence for the cooling trend in the lower stratosphere in the pre-satellite era despite the documented trend uncertainties of the radiosonde data sets during this period (Randel and Wu, 2006; Free and Seidel, 2007; Randel et al. 2009). Furthermore, the inspection of lower stratospheric trends on a monthly basis for all data sets indicate the persistent cooling trends in the lower stratosphere to be a common feature for all months before and after 1980 both at the tropical belt and over the middle latitudes.

The post-1980 lower stratosphere cooling is a common finding in the global mean based on all available satellite and radiosonde data sets while the stratosphere cooling is also reported for the pre-satellite era since 1958 (WMO, 2011; Zerefos and Mantis, 1977). Our post-1980 year-round stratospheric temperature trends at layers L4 (100-50 hPa) and L5 $(50-30 \mathrm{hPa})$ are in the range of calculated trends in Microwave Sounding Unit (MSU) channel $4(15-20 \mathrm{~km})$ and Stratospheric Sounding Unit (SSU) channel $1(25-35 \mathrm{~km})$. MSU channel 4 trends derived from RSS and UAH data show cooling trends over the Northern Hemisphere ranging from -0.2 to $-0.5^{\circ} \mathrm{C} \mathrm{decade}^{-1}$ over the period 1979 2007 (Randel et al., 2009). Comparable cooling trends were obtained for MSU channel 4 after reprocessing by NOAA with the trends at polar latitudes revealing higher uncertainties. The SSU channel 1 trends as processed by the UK Met Office and reprocessed by NOAA show cooling trends ranging from about $-0.5^{\circ} \mathrm{C} \mathrm{decade}^{-1}$ (Met office) to about $-1.1^{\circ} \mathrm{C} \mathrm{decade}^{-1}$ (NOAA) over the period 1979-2005 (Thompson et al., 2012).

These long-term cooling trends in the lower stratosphere can be maintained by increasing GHGs that cool the stratosphere while warming the troposphere (IPCC, 2007 and references therein; Polvani and Solomon, 2012). The post-1980 decrease in stratospheric ozone in late winter-early spring at mid- and polar latitudes of the Northern Hemisphere due to ODSs complicates the issue (Harris et al., 2008). However, the persistence of the cooling trends in the lower stratosphere for all months and especially during the less disturbed summer period with the reduced interannual variance which are observed both before and after 1980 over the tropics and the mid-latitudes indicates that the anthropogenic enhanced greenhouse effect is the most plausible cause for the observed stratospheric quasi-monotonic cooling in the Northern Hemisphere.

At polar latitudes $\left(60-90^{\circ} \mathrm{N}\right)$ the cooling trends in the lower stratosphere are either non-statistically significant or marginally significant at the $95 \%$ confidence level for all data sets. This finding could be related to the competing dynamical and radiative processes that reduce the statistical significance of these trends. A number of modelling studies suggest that the greenhouse warming leads to stronger tropical upwelling and stronger BD circulation (Rind et al., 2001; Cordero and Forster, 2006; Butchart et al., 2006, 2010; Austin and Li, 2006; Rosenlof and Reid, 2008; Garcia and Randel, 2008; Lamarque and Solomon, 2010). The GHGinduced strengthening of BD circulation may lead to a relatively warmer lower stratosphere at higher latitudes thus masking the GHG radiative cooling discussed before. In contrast, over the tropics both dynamical and radiative processes act in the same direction, i.e. the cooling in the lower stratosphere. Our results are in line with other recent studies. For example, Thompson and Solomon (2009) demonstrated that the contrasting latitudinal structures of recent stratospheric temperature (i.e. stronger cooling in the tropical lower stratosphere than in the extratropics) and ozone trends (i.e. enhanced ozone reduction in the tropical lower stratosphere) are consistent with the assumption of increases in the stratospheric overturning BD circulation. Free (2011) also pointed out that the trends in the tropical stratosphere show an inverse relationship with those in the Arctic for 1979-2009, which might be related to changes in stratospheric circulation.

In the troposphere, a common feature in the RICH and NCEP data sets is a non-statistically significant trend or a slight cooling trend until about the end of the 1970s, followed by a warming trend until the present day for the three latitudinal belts. This pre-1980 cooling trend (or absence of trend) in the troposphere is associated with a notable cooling trend from the late 1940s to 1970s (IPCC, 2007), which has been raised as a point of weakness in the theory of $\mathrm{CO}_{2}$-related anthropogenic global warming (Thompson et al., 2010). However, apart from the important role of the decadal natural variability hampering the anthropogenic climate change (Ring et al., 2012; Kosaka and Xie, 2013), anthropogenic aerosols also attracted the scientific interest as a possible cause for this mid-century cooling due to a high concentration of sulfate aerosols emitted in the atmosphere by industrial activities and volcanic eruptions during this period causing the socalled "solar dimming" effect (e.g. Wild et al., 2007; Zerefos et al., 2012). Hence the pre-1980 small cooling trend or insignificant change might be due to natural variability in the ocean-atmosphere system in combination with the compensating role of anthropogenic aerosols in the troposphere. Concerns have been raised recently that increases in aerosol from anthropogenic air pollution and associated dimming of surface solar radiation could have masked to a large extent the temperature rise induced by increasing greenhouse gases, so that the observed temperature records would not reflect the entire dimension of greenhouse warming (Andreae et al., 2005; Wild et al., 2007).

The investigation of the interannual correlation of tropopause pressure with tropospheric and stratospheric temperatures showed a few distinct characteristics. A common feature for the three latitudinal belts in both NCEP and 
CESM1-WACCM is that the influence of tropospheric temperature on the interannual variability of tropopause has a seasonal signal with the tendency to get stronger during the warm period of the year when the tropospheric heating maximizes.

In the tropics $\left(5-30^{\circ} \mathrm{N}\right)$, the interannual variability of lower stratospheric temperature dominates over tropospheric temperature, controlling the interannual variability of the tropopause throughout the year in both NCEP and CESM1WACCM. This could possibly explain why at the tropical zone $\left(5-30^{\circ} \mathrm{N}\right)$ there is a decreasing trend of tropopause pressure (increase of tropopause height) in the pre-1980s. Seidel and Randel (2006) also reported, using radiosonde data, that on the multidecadal scale for tropical atmosphere, the tropopause height change is more sensitive to stratospheric temperature change than tropospheric change and hence at the lowest frequencies the tropopause is primarily coupled with stratospheric temperatures.

At mid-latitudes the tropopause pressure-temperature correlations become generally weaker maximizing from June to September with tropospheric temperatures slightly overwhelming stratospheric temperatures for the control of the interannual variability of tropopause. This is in line with the study of Son et al. (2009) who analysed a set of long-term integrations with stratosphere-resolving CCMs and reported that at mid-latitudes the linear tropopause height increase is controlled by the upper troposphere warming rather than the lower stratosphere cooling. Wu et al. (2013) reported a significant positive correlation between the changes in the tropospheric temperature induced by aerosols and tropopause height at mid-latitudes, the zone between $30^{\circ}$ and $60^{\circ}$ in both hemispheres. Hence taking into account the anthropogenic aerosols variability in the troposphere, the tropopause trends at mid-latitudes may not solely reflect the human-induced climate change signal from GHGs.

At polar latitudes (in NCEP) the interannual variability of lower stratospheric temperature dominates over tropospheric temperature for controlling the interannual variability of the tropopause during the cold part of the year (linked with the development of the polar vortex) while the opposite occurs during the warm period of the year (linked to the higher heating rates of polar troposphere). However, during the late winter-early spring, chemical ozone depletion within the polar Arctic stratosphere in the post-1980 period could further cool the lower stratosphere (in addition to the radiative effect of GHGs) leading possibly to an even higher tropopause. The GHG-induced strengthening of BD circulation, which leads to a relatively warmer lower stratosphere (thus masking the GHG radiative cooling) and lower tropopause, further complicates the issue of using lower stratosphere temperature and tropopause height as climate change indicators at polar latitudes. CESM1-WACCM at polar latitudes does not capture the respective NCEP correlation pattern, an issue that needs further investigation.
The relative contribution of lower stratosphere versus troposphere for the control of tropopause low-frequency variability is an important issue for understanding past and future tropopause trends in view also of the monotonically increasing future tropopause height trends to the end of the 21 st century predicted by both stratosphere-resolving CCMs and the Intergovernmental Panel on Climate Change Fourth Assessment Report (AR4) models (Son et al., 2009).

In conclusion, we provide additional evidence for an early greenhouse cooling signal of the lower stratosphere before 1980, which appears earlier than the tropospheric greenhouse warming signal. As a result, it may be that the stratosphere could have provided an early warning of human-produced climate change. In line with the theoretical expectations that equilibrium temperature in the stratosphere compared to the troposphere is more sensitive to anthropogenic GHGs and less sensitive to tropospheric water vapour, aerosols and clouds, it is tentatively proposed that the stratosphere is more suitable for the detection of man-made climate change signal. We suggest that the maintenance and enrichment of the ground-based and satellite global networks for monitoring stratospheric temperatures and the tropopause region, which adds value in understanding the behaviour of the interface between the troposphere and stratosphere, are essential steps to unravel the issue of future human-induced climate change signals.

\section{The Supplement related to this article is available online at doi:10.5194/acp-14-7705-2014-supplement.}

Acknowledgements. For the University of Illinois, this research was supported in part from NASA under project NASA NNX12AF32G. We acknowledge the support provided by the MariolopoulosKanaginis Foundation for the Environmental Sciences. P. Zanis and J. Luterbacher would like also to acknowledge the support in the framework of the Greece-Germany Exchange and Cooperation Programme, IKYDA 2012. The FU-Berlin data set was obtained by K. Labitzke and Collaborators, 2002: The Berlin Stratospheric Data Series, CD from the Meteorological Institute, Free University Berlin. NCEP Reanalysis-derived data were provided by the NOAA/OAR/ESRL PSD, Boulder, Colorado, USA, from their web site at http://www.cdc.noaa.gov/. The authors would like to thank the anonymous reviewers for their valuable comments and suggestions.

Edited by: E. Gerasopoulos 


\section{References}

Andreae, M. O., Jones, C. D., and Cox, P. M.: Strong present-day aerosol cooling implies a hot future, Nature, 435, 1187-1190, doi:10.1038/nature03671, 2005.

Angell, J. K. and Korshover J.: Global temperature variations in the troposphere and stratosphere, 1958-1982, Mon. Weather Rev., 111, 901-921, 1983.

Austin, J. and Li, F.: On the relationship between the strength of the Brewer-Dobson circulation and the age of stratospheric air, Geophys. Res. Lett., 33, L17807, doi:10.1029/2006GL026867, 2006.

Austin, J., Wilson, R. J., Akiyoshi, H., Bekki, S., Butchart, N., Claud, C., Fomichev, V. I., Forster, P., Garcia, R. R., Gillett, N. P., Keckhut, P., Langematz, U., Manzini, E., Nagashima, T., Randel, W. J., Rozanov, E., Shibata, K., Shine, K. P., Struthers, H., Thompson, D. W. J., Wu, F., and Yoden, S.: Coupled chemistry climate model simulations of stratospheric temperatures and their trends for the recent past, Geophys. Res. Lett., 36, L13809, doi:10.1029/2009GL038462, 2009.

Berger, U., and F.-J. Lübken: Mesospheric temperature trends at midlatitudes in summer, Geophys. Res. Lett., 38, L22804, doi:10.1029/2011GL049528, 2011.

Butchart, N.: The Brewer-Dobson Circulation, Rev. Geophys., 52, 157-184, doi:10.1002/2013RG000448, 2014.

Butchart, N., Scaife, A. A., Bourqui, M., de Grandpré, J., Hare, S. H. E., Kettleborough, J., Langematz, U., Manzini, E., Sassi, F., Shibata, K., Shindell, D., and Sigmond, M.: Simulations of anthropogenic change in the strength of the Brewer-Dobson circulation, Clim. Dynam., 27, 727-741, doi:10.1007/s00382-0060162-4, 2006.

Butchart, N., Cionni, I., Eyring, V., Shepherd, T. G., Waugh, D. W., Akiyoshi, H., Austin, J., Brhl, C., Chipperfield, M. P., Cordero, E., Dameris, M., Deckert, R., Dhomse, S., Frith, S. M., Garcia, R. R., Gettelman, A., Giorgetta, M. A., Kinnison, D. E., Li, F., Mancini, E., McLandress, C., Pawson, S., Pitari, G., Plummer, D. A., Rozanov, E., Sassi, F., Scinocca, J. F., Shibata, K., Steil, B., and Tian, W.: Chemistry-climate model simulations of twentyfirst century stratospheric climate and circulation change, J. Climate., 23, 5349-5374, doi:10.1175/2010JCLI3404.1, 2010.

Christy, J. R., Spencer, R. W., Norris, W. B., Braswell, W. D., and Parker, D. E.: Error estimates of version 5.0 of MSU-AMSU bulk atmospheric temperatures, J. Atmos. Ocean. Tech., 20, 613-629, 2003.

Cordero, E. C. and Forster, P. M. de F.: Stratospheric variability and trends in models used for the IPCC AR4, Atmos. Chem. Phys., 6, 5369-5380, doi:10.5194/acp-6-5369-2006, 2006.

Crooks, S. A. and Gray, L. J.: Characterization of the 11-year solar signal using a multiple regression analysis of the ERA-40 dataset, J. Climate, 18, 996-1015, 2005.

Engel, A., Möbius, T., Bönisch, H., Schmidt, U., Heinz, R., Levin, I., Atlas, E., Aoki, S., Nakazawa, T., Sugawara, S., Moore, F., Hurst, D., Elkins, J., Schauffler, S., Andrews, A., and Boering, K.: Age of stratospheric air unchanged within uncertainties over the past 30 years, Nat. Geosci., 2, 28-31, doi:10.1038/ngeo388, 2009.

Free, M.: The Seasonal Structure of Temperature Trends in the Tropical Lower Stratosphere, J. Climate, 24, 859-866, doi:10.1175/2010JCLI3841.1, 2011.
Free, M. and Lanzante, J.: Effect of volcanic eruptions on the vertical temperature profile in radiosonde data and climate models, J. Climate, 22, 2925-2939, doi:10.1175/2008JCLI2562.1, 2009.

Free, M. and Seidel D. J.: Comments on "Biases in Stratospheric and Tropospheric Temperature Trends Derived from Historical Radiosonde Data", J. Climate, 20, 3704-3709, doi:10.1175/JCLI4210.1, 2007.

Free, M., Seidel, D. J., Angell, J. K., Lanzante, J., Durre, I., and Peterson, T. C.: Radiosonde Atmospheric Temperature Products for Assessing Climate (RATPAC): A new data set of large-area anomaly time series, J. Geophys. Res., 110, D22101, doi:10.1029/2005JD006169, 2005.

Fioletov, V. E.: Estimating the 27-day and 11-year solar cycle variations in tropical upper stratospheric ozone, J. Geophys. Res., 114, D02302, doi:10.1029/2008JD010499, 2009.

Fu, Q., Solomon, S., and Lin, P.: On the seasonal dependence of tropical lower-stratospheric temperature trends, Atmos. Chem. Phys., 10, 2643-2653, doi:10.5194/acp-10-2643-2010, 2010.

Garcia, R. R. and Randel, W. J.: Acceleration of the Brewer-Dobson circulation due to increases in greenhouse gases, J. Atmos. Sci., 65, 2731-2739, doi:10.1175/2008JAS2712.1, 2008.

Gettelman, A., Hoor, P., Pan, L. L., Randel, W. J., Hegglin, M. I., and Birner, T: The extratropical upper troposphere and lower stratosphere, Rev. Geophys., 49, RG3003, doi:10.1029/2011RG000355, 2011.

Haimberger, L.: Homogenization of radiosonde temperature time series using innovation statistics, J. Climate, 20, 1377-1403, doi:10.1175/JCLI4050.1, 2007.

Haimberger, L., Tavolato, C., and Sperka, S.: Toward elimination of the warm bias in historic radiosonde temperature records - Some new results from a comprehensive intercomparison of upper-air data, J. Climate, 21, 4587-4606, doi:10.1175/2008JCLI1929.1, 2008.

Harris, N. R. P., Kyrö, E., Staehelin, J., Brunner, D., Andersen, S.B., Godin-Beekmann, S., Dhomse, S., Hadjinicolaou, P., Hansen, G., Isaksen, I., Jrrar, A., Karpetchko, A., Kivi, R., Knudsen, B., Krizan, P., Lastovicka, J., Maeder, J., Orsolini, Y., Pyle, J. A., Rex, M., Vanicek, K., Weber, M., Wohltmann, I., Zanis, P., and Zerefos, C.: Ozone trends at northern mid- and high latitudes - a European perspective, Ann. Geophys., 26, 1207-1220, doi:10.5194/angeo-26-1207-2008, 2008.

He, Q., Li, C., Mao, J., Lau, A. K.-H., and Chu, D. A.: Analysis of aerosol vertical distribution and variability in Hong Kong, J. Geophys. Res., 113, D14211, doi:10.1029/2008JD009778, 2008.

Holland, M. M., Bailey, D. A., Briegleb, B. P., Light, B., and Hunke, E.: Improved Sea Ice Shortwave Radiation Physics in CCSM4: The Impact of Melt Ponds and Aerosols on Arctic Sea Ice, J. Climate, 25, 1413-1430, doi:10.1175/JCLI-D-11-00078.1, 2012.

$\mathrm{Hu}, \mathrm{Y}$. and Fu, Q.: Stratospheric warming in Southern Hemisphere high latitudes since 1979, Atmos. Chem. Phys., 9, 4329-4340, doi:10.5194/acp-9-4329-2009, 2009.

IPCC, Climate Change 2007: The Physical Science Basis. Contribution of Working Group I to the Fourth Assessment, Report of the Intergovernmental Panel on Climate Change, edited by: Solomon, S., Qin, D., Manning, M., Chen, Z., Marquis, M., Averyt, K. B., Tignor M., and Miller, H. L., Cambridge University Press, Cambridge, United Kingdom and New York, NY, USA, 996 pp., 2007. 
IPCC, Climate Change 2013: The Physical Science Basis. Contribution of Working Group I to the Fifth Assessment Report of the Intergovernmental Panel on Climate Change, edited by: Stocker, T. F., Qin, D., Plattner, G.-K., Tignor, M., Allen, S. K., Boschung, J., Nauels, A., Xia, Y., Bex, V., and Midgley, P. M., Cambridge University Press, Cambridge, United Kingdom and New York, NY, USA, 1535 pp., 2013.

Iwasaki, T., Hamada, H., and Miyazaki, K.: Comparisons of Brewer-Dobson circulations diagnosed from reanalyses, J. Meteorol. Soc. Jpn., 87, 997-1006, doi:10.2151/jmsj.87.997, 2009.

Johanson, C. M. and Fu, Q.: Antarctic atmospheric temperature trend patterns from satellite observations, Geophys. Res. Lett., 34, L12703, doi:10.1029/2006GL029108, 2007.

Kalnay, E., Kanamitsu, M., Kistler, R., Collins, W., Deaven, D., Gandin, L., Iredell, M., Saha, S., White, G., Woollen, J., Zhu, Y., Leetmaa, A., Reynolds, R., Chelliah, M., Ebisuzaki, W., Higgins, W., Janowiak, J., Mo, K. C., Ropelewski, C., Wang, J., Jenne, R., and Joseph, D.: The NCEP/NCAR 40-Year Reanalysis Project, B. Am. Meteor. Soc., 77, 437-471, 1996.

Kawatani, Y. and Hamilton, K.: Weakened stratospheric quasibiennial oscillation driven by increased tropical mean upwelling, Nature, 497, 478-481, doi:10.1038/nature12140, 2013.

Kinnison, D. E., Brasseur, G. P., Walters, S., Garcia, R. R., Marsh, D. R., Sassi, F., Harvey, V. L., Randall, C. E., Emmons, L., Lamarque, J. F., Hess, P., Orlando, J. J., Tie, X. X., Randel, W., Pan, L. L., Gettelman, A., Granier, C., Diehl, T., Niemeier, U., and Simmons, A. J.: Sensitivity of chemical tracers to meteorological parameters in the MOZART-3 chemical transport model, J. Geophys. Res., 112, D20302, doi:10.1029/2006JD007879, 2007.

Kistler, R., Kalnay, E., Collins, W., Saha, S., White, G., Woollen, J., Chelliah, M., Ebisuzaki, W., Kanamitsu, M., Kousky, V., van den Dool, H., Jenne, R., and Fiorino, M.: The NCEP-NCAR 50Year Reanalysis: Monthly Means CD-ROM and Documentation, B. Am. Meteor. Soc., 82, 247-267, 2001.

Kosaka, Y., and Xie, S. P.: Recent global-warming hiatus tied to equatorial Pacific surface cooling, Nature, 501, 403-407, doi:10.1038/nature12534, 2013.

Labitzke, K. and Collaborators: The Berlin Stratospheric Data Series, Meteorological Institute, Free University Berlin, CD-ROM, 2002.

Labitzke, K. and Kunze, M.: Stratospheric temperatures over the Arctic: Comparison of three data sets, Meteorol. Z., 14, 65-74, 2005.

Lamarque, J.-F. and Solomon S.: Impact of changes in climate and halocarbons on recent lower stratospheric ozone and temperature trends, J. Climate, 23, 2599-2611, doi:10.1175/2010JCLI3179.1, 2010.

Lin, P., Fu, Q., Solomon, S., and Wallace, J. M.: Temperature trend patterns in Southern Hemisphere high latitudes: novel indicators of stratospheric changes, J. Climate, 22, 6325-6341, doi:10.1175/2009JCLI2971.1, 2009.

Manabe, S. and Weatherald, R. T.: Thermal equilibrium of the atmosphere with a given distribution of relative humidity, J. Atmos. Sci., 24, 241-259, 1967.

Manney, G. L., Krüger, K. Sabutis, J. L., Sena, S. A., and Pawson, S.: The remarkable 2003-2004 winter and other recent warm winters in the Arctic stratosphere since the late 1990s, J. Geophys. Res., 110, D04107, doi:10.1029/2004JD005367, 2005.
Marsh, D. R., Mills, M. J., Kinnison, D. E., Lamarque, J.-F., Calvo, N., and Polvani, L. M.: Climate Change from 1850 to 2005 Simulated in CESM1(WACCM), J. Climate, 26, 7372-7391, doi:10.1175/JCLI-D-12-00558.1, 2013.

Mantis, H. T. and Zerefos, C. S.: Fluctuations in the Northern Hemisphere stratospheric temperature on time scales from ten years to two months, Arch. Meteor. Geophy. A, 28, 127-147, 1979.

Mears, C. A. and Wentz, F. J.: Construction of the Remote Sensing Systems V3.2 atmospheric temperature records from the MSU and AMSU microwave sounders, J. Atmos. Ocean. Tech., 26, 1040-1056, doi:10.1175/2008JTECHA1176.1, 2009.

Miller, A. J., Nagatani, R. M., Tiao, G. C., Niu, X. F., Reinsel, G. C., Wuebbles, D., and Grant, K.: Comparisons of observed ozone and temperature trends in the lower stratosphere, Geophys. Res. Lett., 19, 929-932, 1992.

Polvani, L. M. and Solomon, S.: The signature of ozone depletion on tropical temperature trends, as revealed by their seasonal cycle in model integrations with single forcings, J. Geophys. Res., 117, D17102, doi:10.1029/2012JD017719, 2012.

Randel, W. J. and Thompson, A. M.: Interannual variability and trends in tropical ozone derived from SAGE II satellite data and SHADOZ ozonesondes, J. Geophys. Res., 116, D07303, doi:10.1029/2010JD015195, 2011.

Randel, W. J. and Wu, F.: Biases in stratospheric and tropospheric temperature trends derived from historical radiosonde data, J. Climate, 19, 2094-2104, 2006.

Randel, W. J., Udelhofen, F., Fleming, E., Geller, M., Gelman, M., Hamilton, K., Karoly, D., Ortland, D., Pawson, S., Swinbank, R., Wu, F., Baldwin, M., Chanin, M., Keckhut, P., Labitzke, K., Remsberg, E., Simmons, A., and Wu, D.: The SPARC intercomparison of middle-atmosphere climatologies, J. Climate, 17, 986-1003, 2004.

Randel, W. J., Shine, K. P., Austin, J., Barnett, J., Claud, C., Gillet, N. P., Keckhut, P., Langematz, U., Lin, R., Long, C., Mears, C., Miller, A., Nash, J., Seidel, D. J., Thompson, D. W. J., Wu, F., and Yoden, S.: An update of observed stratospheric temperature trends, J. Geophys. Res., 114, D02107, doi:10.1029/2008JD010421, 2009.

Ramaswamy, V., Schwarzkopf, M. D., Randel, W. J., Santer, B. D., Soden, B. J., and Stenchikov, G. L.: Anthropogenic and natural influences in the evolution of lower stratospheric cooling, Science, 311, 1138-1141, doi:10.1126/science.1122587, 2006.

Reinsel, G. C.: Trend analysis of upper stratospheric Umkehr ozone data for evidence of turnaround, Geophys. Res. Lett., 29, 1451, doi:10.1029/2002GL014716, 2002.

Reinsel, G. C., Miller, A. J., Weatherhead, E. C., Flynn, L. E., Nagatani, R. M., Tiao, G. C., and Wuebbles D. J.: Trend analysis of total ozone data for turnaround and dynamical contributions, J. Geophys. Res., 110, D16306, doi:10.1029/2004JD004662, 2005.

Rind, D., Lerner, J., and McLinden, C.: Changes of tracer distributions in the doubled $\mathrm{CO}_{2}$ climate, J. Geophys. Res., 106, 2806128079, doi:10.1029/2001JD000439, 2001.

Ring M. J., Lindner, D., Cross, E. M., and Schlesinger, M. E.: Causes of the Global Warming Observed since the 19th Century, Atmospheric and Climate Sciences, 2, 401-415, doi:10.4236/acs.2012.24035, 2012.

Rosenlof, K. H. and Reid, G. C.: Trends in the temperature and water vapor content of the tropical lower strato- 
sphere: Sea surface connection, J. Geophys. Res., 113, D06107, doi:10.1029/2007JD009109, 2008.

Santer, B. D., Hnilo, J. J., Wigley, T. M. L., Boyle, J. S., Doutriaux, C., Fiorino, M., Parker, D. E., and Taylor, K. E.: Uncertainties in observationally based estimates of temperature change in the free atmosphere, J. Geophys. Res., 104, 63056333, doi:10.1029/1998JD200096, 1999.

Santer, B. D., Sausen, R., Wigley, T. M. L., Boyle, J. S., AchutaRao, K., Doutriaux, C., Hansen, J. E., Meehl, G. A., Roeckner, E., Ruedy, R., Schmidt, G., and Taylor, K. E.: Behavior of tropopause height and atmospheric temperature in models, reanalyses, and observations: Decadal changes, J. Geophys. Res., 108, 4002, doi:10.1029/2002JD002258, 2003a.

Santer, B. D., Wehner, M. F., Wigley, T. M. L., Sausen, R., Meehl, G. A., Taylor, K. E., Ammann, C., Arblaster, J., Washington, W. M., Boyle, J. S., and Brüggemann, W.: Contributions of anthropogenic and natural forcing to recent tropopause height changes, Science, 301, 479-483, doi:10.1126/science.1084123, 2003b.

Santer, B. D., Painter, J. F., Mears, C. A., Doutriaux, C., Caldwell, P., Arblaster, J. M., Cameron-Smith, P. J., Gillett, N. P., Gleckler, P. J., Lanzante, J., Perlwitz, J., Solomon, S., Stott, P. A., Taylor, K. E., Terray, L., Thorne, P. W., Wehner, M. F., Wentz, F. J., Wigley, T. M. L., Wilcox, L. J., and Zou, C.: Identifying human influences on atmospheric temperature, P. Natl. Acad. Sci. USA, 110, 26-33, 2013.

Sato, M., Hansen, J. E., McCormick, M. P., and Pollack, J. B.: Stratospheric aerosol optical depth, 1850-1990, J. Geophys. Res., 98, 22987-22994, 1993.

Seidel, D. J. and Randel, W. J.: Variability and trends in the global tropopause estimated from radiosonde data, J. Geophys. Res., 111, D21101, doi:10.1029/2006JD007363, 2006.

Sherwood, S. C., Meyer, C. L., Allen, R. J., and Titchner, H. A.: Robust tropospheric warming revealed by iteratively homogenized radiosonde data, J. Climate, 21, 5336-5350, doi:10.1175/2008JCLI2320.1, 2008.

Shine, K. P., Bourqui, M. S., Forster, P. M. de F., Hare, S. H. E., Langematz, U., Braesicke, P., Grewe, V., Ponater, M., Schnadt, C., Smith, C. A., Haigh, J. D., Austin, J., Butchart, N., Shindell, D. T., Randel, W. J., Nagashima, T., Portmann, R. W., Solomon, S., Seidel, D. J., Lanzante, J., Klein, S., Ramaswamy, V., and Schwarzkopf, M. D.: A comparison of model-simulated trends in stratospheric temperatures, Q. J. Roy. Meteor. Soc., 129, 15651588, doi:10.1256/qj.02.186, 2003.

Son, S.-W., Polvani, L. M., Waugh, D. W., Birner, T., Akiyoshi, H., Garcia, R. R., Gettelman, A., Plummer, D. A., and Rozanov, E.: The Impact of Stratospheric Ozone Recovery on Tropopause Height Trends, J. Climate, 22, 429-445, doi:10.1175/2008JCLI2215.1, 2009.

Staehelin, J., Harris, N. R. P., Appenzeller, C., and Eberhard, J.: Ozone trends: A review, Rev. Geophys., 39, 231-290, 2001.

Tiao, G. C., Reinsel, G. C., Xu, D., Pedrick, J. H., Zhu, X., Miller, A. J., DeLuisi, J. J., Mateer, C. L., and Wuebbles, D. J.: Effects of autocorrelation and temporal sampling schemes on estimates of trend and spatial correlation, J. Geophys. Res., 95, 20507-20517, 1990.
Thompson, D. W. J. and Solomon, S.: Recent stratospheric climate trends as evidenced in radiosonde data: Global structure and tropospheric linkages, J. Climate, 18, 4785-4795, 2005.

Thompson, D. W. J. and Solomon, S.: Understanding recent stratospheric climate change, J. Climate, 22, 1934-1943, doi:10.1175/2008JCLI2482.1, 2009.

Thompson, D. W. J., Wallace, J. M., Kennedy, J. J., and Jones, P. D.: An abrupt drop in Northern Hemisphere sea surface temperature around 1970, Nature, 467, 444-447, doi:10.1038/nature09394, 2010.

Thompson, D. W. J., Seidel, D. J., Randel, W. J., Zou, C.-Z., Butler, A. H., Mears, C., Osso, A., Long, C., and Lin, R.: The mystery of recent stratospheric temperature trends, Nature, 491, 692-697, doi:10.1038/nature11579, 2012.

Thorne, P. W., Parker, D. E., Tett, S. F. B., Jones, P. D., McCarthy, M., Coleman, H., and Brohan, P.: Revisiting radiosonde upper air temperatures from 1958 to 2002, J. Geophys. Res., 110, D18105, doi:10.1029/2004JD005753, 2005.

Webb, W. L.: Structure of the stratosphere and mesosphere, New York and London, Academic Press, 380 pp., 183 Figures, 1966.

Wild, M., Ohmura, A., and Makowski, K.: Impact of global dimming and brightening on global warming, Geophys. Res. Lett., 34, L04702, doi:10.1029/2006GL028031, 2007.

WMO (World Meteorological Organization), Scientific Assessment of Ozone Depletion: 2006, Global Ozone Research and Monitoring Project-Report No. 50, 572 pp., Geneva, Switzerland, 2007.

WMO (World Meteorological Organization), Scientific Assessment of Ozone Depletion: 2010, Global Ozone Research and Monitoring Project-Report No. 52, 516 pp., Geneva, Switzerland, 2011.

Wu, J., Xu, Y, Yang, Q., Han, Z., Zhao, D., and Tang, J.: A numerical simulation of aerosols' direct effects on tropopause height, Theor. Appl. Climatol., 112, 659-671, doi:10.1007/s00704-0120760-5, 2013.

Zerefos, C. S. and Mantis, H. T.: Climatic fluctuations in the Northern Hemisphere stratosphere, Arch. Meteor. Geophy. B, 25, 33 39, 1977.

Zerefos, C. S., Bais, A. F., Ziomas, I. C., and Bojkov, R. D.: On the relative importance of quasi-biennial oscillation and El Nino/southern oscillation in the revised Dobson total ozone records, J. Geophys. Res., 97, 10135-10144, doi:10.1029/92JD00508, 1992.

Zerefos, C. S., Tourpali, K., Eleftheratos, K., Kazadzis, S., Meleti, C., Feister, U., Koskela, T., and Heikkilä, A.: Evidence of a possible turning point in solar UV-B over Canada, Europe and Japan, Atmos. Chem. Phys., 12, 2469-2477, doi:10.5194/acp-12-24692012, 2012.

Zou, C.-Z., Gao, M., and Goldberg, M. D.: Error structure and atmospheric temperature trends in observations from the Microwave Sounding Unit, J. Climate, 22, 1661-1681, doi:10.1175/2008JCLI2233.1, 2009. 